\title{
Os museus históricos e pedagógicos do estado de São Paulo
}

\begin{abstract}
Simona Misan ${ }^{1}$
RESUMO: Este estudo analisa a criação da rede de museus históricos e pedagógicos do estado de São Paulo entre os anos de 1956 e 1973, sobretudo quanto ao conceito de criação, de programa e de função de museu na sociedade. Tal análise estende-se ao final da década de 1990, quando a tutela dos museus, até então estadual, é transferida às cidades por meio do processo de municipalização, coordenado pelo Departamento de Museus e Arquivos, da Secretaria de Estado da Cultura (Dema-SEC). Em meio a outras iniciativas nos campos da educação e da cultura, aborda a correspondência existente entre a implantação da rede desses museus e antigas necessidades de afirmação identitária, ao evidenciar, por meio de projetos desta natureza, o caráter hegemônico do Estado e sua atuação em campos como o da história, o da educação e o da cultura. Isso permitiu alinhar a iniciativa de criação dos museus a outras anteriormente promovidas pelo estado de São Paulo e possibilitar que o tema escapasse de um prolongado isolamento no estudo da história paulista. Trata, também, da trama de relações existentes entre diversos setores ligados aos museus - educação, cultura, Instituto Histórico e Geográfico de São Paulo (IHGSP), poder público e sociedade. A hipótese central é de que a implantação desses museus correspondeu plenamente às aspirações da sociedade de uma época, ao mesmo tempo em que evidencia a lógica da ideação que determinou o modo característico de atuação dos museus nos anos em que estiveram sob a tutela do governo estadual, propondo, assim, entendê-los como paradigma de "museu histórico do estado de São Paulo".

PALAVRAS-CHAVE: Museus históricos e pedagógicos. Museologia. História da cultura. Estado de São Paulo. Coleções. Vinício Stein Campos.
\end{abstract}

ABSTRACT: This paper analyzes the creation of the Historical and Pedagogical Museums network in the State of São Paulo between 1956 and 1973, mainly taking into consideration the concept for creation, the program, and the role of the museum in society. This work covers a period until the end of the 1990's, when the curators of the museums, which belonged to the State until that time, was transferred to the municipalities by means of a "municipalization" process coordinated by the Department of Museums and Archives of the State Department of
1. Arquiteta. Doutora em História Social pelo Departamento de História da Faculdade de Filosofia, Letras e Ciências Humanas da Universidade de São Paulo. Bolsista Fapesp. Apoio: DemaSEC. E-mail: simona@museu mcultural.com.br. 
2. Ver Vinício Stein Campos (1960, p. 61).
Cultural Affairs (DEMA-SEC). It also shows that the implementation of this museums network among other initiatives in the fields of education and of culture - addressed earlier needs of asserting an identity, emphasizing through projects of this type the hegemonic character of the State. This allowed to align the initiative of creating the museums with others actions carried out by the State before, and also enabled that this topic was take out from its long isolation from the study of State history. It also considers the web of relationships existing among the various sectors with which museums were connected, such as education, culture, and the São Paulo Historical and Geographical Institute, the Government, and Society. The implementation of Historical and Pedagogical Museums by means of State action, through its Departments of Education (from 1956 to 1968) and Cultural Affairs (from 1968 to 1998) was one of the ways through which the Government orientated its activities during those years in the fields of history, education and culture. The central thesis is that the implementation of these museums has fully addressed the aspirations of society at the time, while, at the same time, underscoring the logic behind the ideation that has oriented the characteristic mode of operation of museums during the years in which their curatorship was exercised by the Government, and proposes to consider them as a paradigm for "historical museums of the State of São Paulo".

KEYWORDS: Museums and historical education. Museology. History of culture. State of São Paulo. Collections. Vinício Stein Campos.

Revelar as razões que promoveram a implantação da rede de museus históricos e pedagógicos do estado de São Paulo foi o objetivo central deste estudo. Num segundo momento, foi possível formular questões estruturais relacionadas ao desenvolvimento da pesquisa empreendida, permitindo uma análise mais aprofundada dos laços entre a implantação dos museus e as condicionantes histórico-culturais do período.

A principal questão levantada foi identificar qual a estratégia estabelecida na implantação dos museus, utilizando-se como ponto de partida o lema proposto por seu criador, Vinício Stein Campos: "preservar a história da cidade e do patrono" 2 .

Decretos estaduais criaram os museus históricos e pedagógicos nas décadas de 1950 a 1970, colocando-os sob a direção do Serviço de Museus Históricos, órgão pertencente à Secretaria de Educação do Estado de São Paulo, e instalando-os em diversas cidades do interior de São Paulo. Hoje, eles constituem a maior rede de museus históricos e públicos criada no país. Em 1968, os museus foram transferidos à Secretaria de Estado da Cultura, passando à guarda e administração do Departamento de Museus e Arquivos (Dema-SEC). Em 1998, a tutela dos museus, até então do Estado, é transferida às respectivas cidades por meio do processo de municipalização, coordenado pelo Dema-SEC.

Tal estratégia, denominada "Implantação dos museus históricos e pedagógicos do estado de São Paulo", permitiu ao poder estadual afirmar-se no campo da cultura e da educação de modo hegemônico, relegando ao município a cessão do imóvel, o deslocamento de professores da rede pública para a direção dos museus, e o auxílio na coleta e no armazenamento do acervo. Ao impor-se na criação, direção e organização da rede de museus, o governo estadual pôde priorizar e preservar um determinado ponto de vista sobre a 
história do estado de São Paulo, relegando outros focos, como por exemplo, a própria história das cidades. Com base nisso, pode-se dizer que esta foi uma das estratégias - aplicada ao longo de cerca de cinqüenta anos - usada pelo poder público estadual para subsidiar e garantir sua supremacia em campos como o da Cultura e da Educação. $\bigcirc$ resultado, legado como herança dessa longa gestão, foi o delineamento, a adoção e a manutenção de um modelo paradigmático de museu histórico do interior de São Paulo.

\section{A criação dos museus históricos e pedagógicos}

Foi em 1956 que Sólon Borges dos Reis ${ }^{3}$, então Diretor Geral do Departamento de Educação da Secretaria de Estado dos Negócios da Educação, propôs ao secretário Vicente de Paula Lima a criação dos primeiros museus históricos e pedagógicos (MHP) $)^{4}$ : MHP Prudente de Morais (Piracicaba), MHP Campos Salles (Campinas), MHP Rodrigues Alves (Guaratinguetá), e MHP Washington Luís (Batatais). A intenção era criar centros de memória e de pesquisa acerca da vida dos quatro presidentes republicanos oriundos do estado de São Paulo.

No ano seguinte, Borges dos Reis afasta-se da Secretaria de Educação e convida Vinício Stein Campos ${ }^{5}$ para assumir a direção do Serviço de Museus Históricos. Nesse mesmo ano, Stein redige o regulamento dos museus ${ }^{6}$ e propõe a criação de mais cinco deles: 7 MHP Cesário Motta (Capivari), MHP dos Andradas (Santos), MHP D.Pedro I e D. Leopoldina (Pindamonhangaba), MHP Brigadeiro Tobias Aguiar (Sorocaba) e MHP das Monções (Porto Feliz). Em 1958, por iniciativa particular de Borges dos Reis, é aprovado novo decreto ${ }^{8}$ para instalação do MHP Visconde Taunay e Affonso de Taunay (Casa Branca) ${ }^{9}$ e, ainda no mesmo ano, por meio de novo decreto, Stein cria dezenove museus novos e classifica o conjunto total formado por vinte e seis unidades, em três períodos históricos distintos: ${ }^{10}$ o Colonial, o Monárquico e o Republicano.

De 1960 a 1973 foram criados mais cinqüenta e um museus que, segundo Stein, passam a configurar uma rede de museus, concentrados sobretudo na porção ocidental do estado como é possível observar num mapa publicado pelo Serviço de Museus Históricos (Figura 1)11. No ano de 1973, a rede contabilizava setenta e nove unidades ${ }^{12}$.

Vultos e cidades "tecem" a história

Desde o início da criação dos primeiros MHP, foi prática estabelecida que, para cada museu criado, fosse indicado o nome de um patrono a ser rememorado. Em sua maioria, tais patronos eram personagens importantes na história de fundação da cidade, ou tiveram destaque na política estadual ou do país. Partindo dessa premissa, uma das principais questões no estudo dos MHP
3. Sólon Borges dos Reis (1917-2006), diplomado em Pedagogia pela USP. Um dos fundadores da Associação dos Professores do Ensino Oficial do Estado de São Paulo (1945) e da União Paulista de Educação (1947). Deputado estadual (19591979), presidiu a Comissão de Educação e da Cultura na Assembléia Legislativa. Presidente do Centro do Professorado Paulista (1956-1997). Secretário Municipal de Educação (1993-1996)

4. Decreto $\mathrm{n}^{\circ} 26.218$, de 3.8.1956.

5. Vinício Stein Campos (1908 - 1990), diplomado em Pedagogia, em 1932, em Santa Bárbara d'Oeste, onde lançou o semanário $O$ Constitucionalista. Sócio do IHGSP (1952-1990). Diretor da Divisão de Museus, da Coordenadoria do Patrimônio Cultural, da Secretaria de Cultura, Esportes e Turismo do Governo do Estado de São Paulo, Conselheiro do Condephaat, membro da Associação dos Cavaleiros de São Paulo, do Atheneu Paulista de História e do Centro de Ciências, Letras e Artes e da Academia Campinense de Letras. Autor de Elementos de Museologia (ca. de 1970).

6. Ato $\mathrm{n}^{\circ} 19$, de 30. 4.1957 .

7. Decreto $\mathrm{n}^{\circ} 30.324, \mathrm{de}$ 10.12.1957

8. Decreto $\mathrm{n}^{\circ} 32.203$, de 10.2.1958

9. Cidade natal de Sólon Borges dos Reis.

10. Dos 26 MHP, três museus indicados por Vinício Stein como folclóricos e religiosos - MHPF Cornélio Pires (Tietê), MHPF Monteiro Lobato (Taubaté), Museu de Arte Religiosa e Música Sacra Jesuíno do Monte Carmelo (Itu) - não foram inscritos nesta classificação.

11. A partir de 1959 , os mu- 


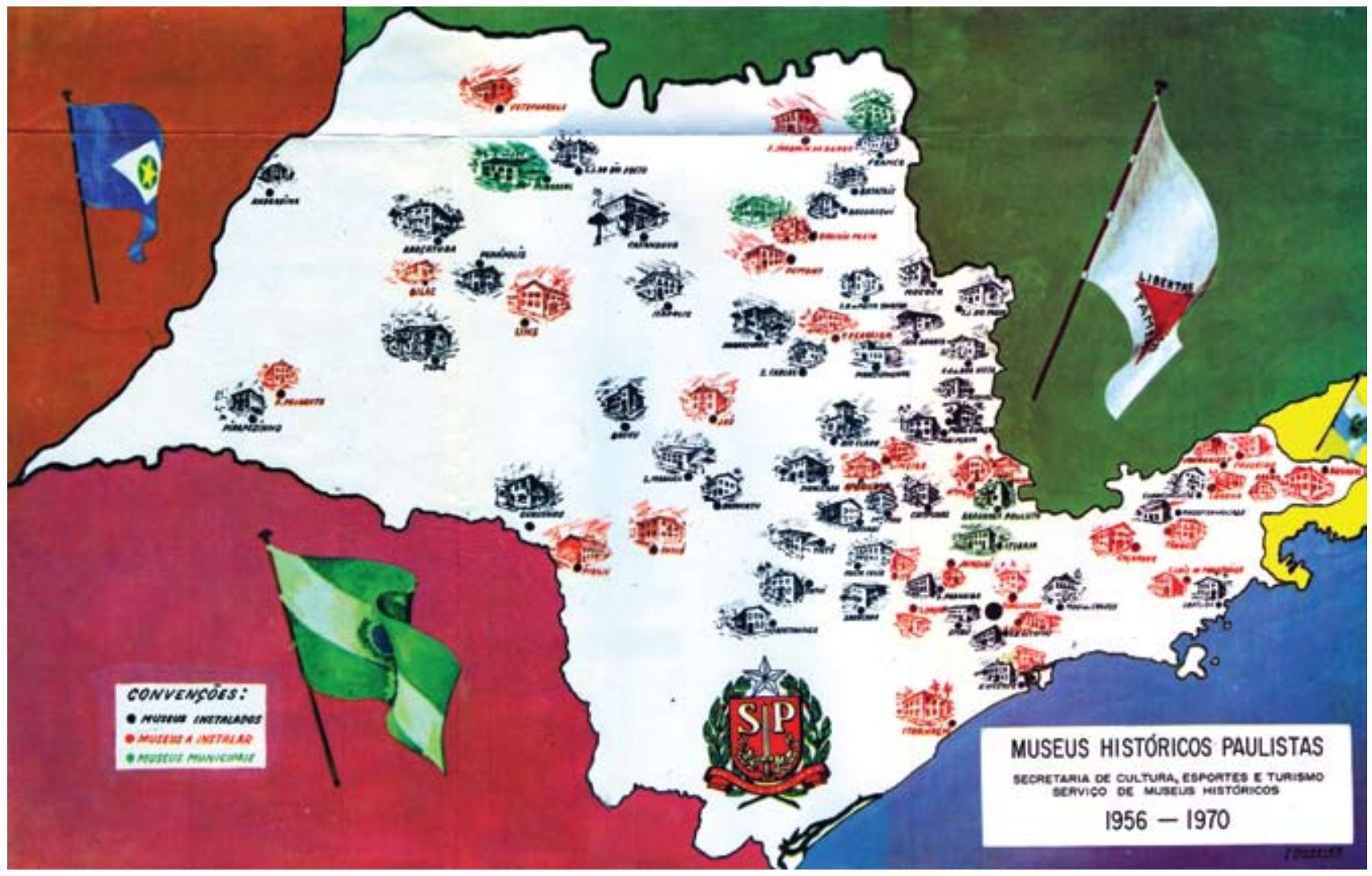

Figura 1 - Museus Históricos Paulistas (1956 - 1970). In: CAMPOS, Vinício Stein. Elementos de museologia. História dos museus - Brasil, São Paulo: Secretaria de Esportes e Turismo - Serviço de Museus Históricos, vol. III, c. 1970.

seus foram criados com base no mesmo decreto $\mathrm{n}^{\circ}$ 33.980 , de 19.11 .1959

12 Nem todos os museus criados por decreto foram instalados. Do total de 79 MHP, foram instaladas 53 unidades. foi procurar entender quais os parâmetros adotados por Stein para o binômio patrono-cidade estabelecido para cada museu. Paralelamente a tal investigação, analisou-se a relação desses parâmetros com a existência de um possível plano de implantação geográfica, estabelecido por Stein, para o assentamento de museus pelo interior do Estado. Um caminho a seguir seria o de analisar mais detalhadamente as razões que levaram Stein a criar o primeiro MHP, sob sua direção.

Da relação dos cinco museus criados por ele, o primeiro deles, em 1957, foi o MHP Cesário Motta, instalado em Capivari, cidade natal de Vinício Stein. E Cesário Motta? Qual seria a relação, uma vez que o patrono vivera apenas alguns anos em Capivari? Na história política de São Paulo, a maior atuação de Cesário Motta fora na capital, onde, entre outras atividades, exercera a presidência do Instituto Histórico e Geográfico. Talvez sua atividade no IHGSP revelasse algum elo de ligação com Stein e com a escolha da cidade de Capivari, para a implantação do primeiro museu. E revelou, pois Stein também fora membro ativo do IHGSP. 
Com base em considerações como essa, uma investigação mais atenta ao sistema praticado pelo IHGSP para a admissão de sócios e para a eleição de patronos revelou algumas descobertas fundamentais para este estudo.

Em 1952, quando Stein ingressa como sócio efetivo no $\|_{\text {HGSPl3, }}$ também teve de escolher seu patrono. Assim, cumpria uma antiga tradição, dos institutos históricos e geográficos, de eleger para cada novo sócio um patrono que fosse também um antigo membro do Instituto. Não por coincidência, Stein elege Cesário Motta. Assim sendo, homenageia tanto seu patrono quanto sua cidade natal no primeiro museu que criou, instalado no Paço Municipal (Figura 2).

No estado de São Paulo, homenagear vultos históricos por meio da nomeação de edifícios públicos é prática antiga, anterior à criação dos MHP.
13 Sócio efetivo do IHGSP, em 5.7.1952. Posse do Titular. Notícia da cerimônia de 19. 7.1952. Revista do IHGSP, São Paulo, v. 60, n. 51, p. 382-383, 1964.

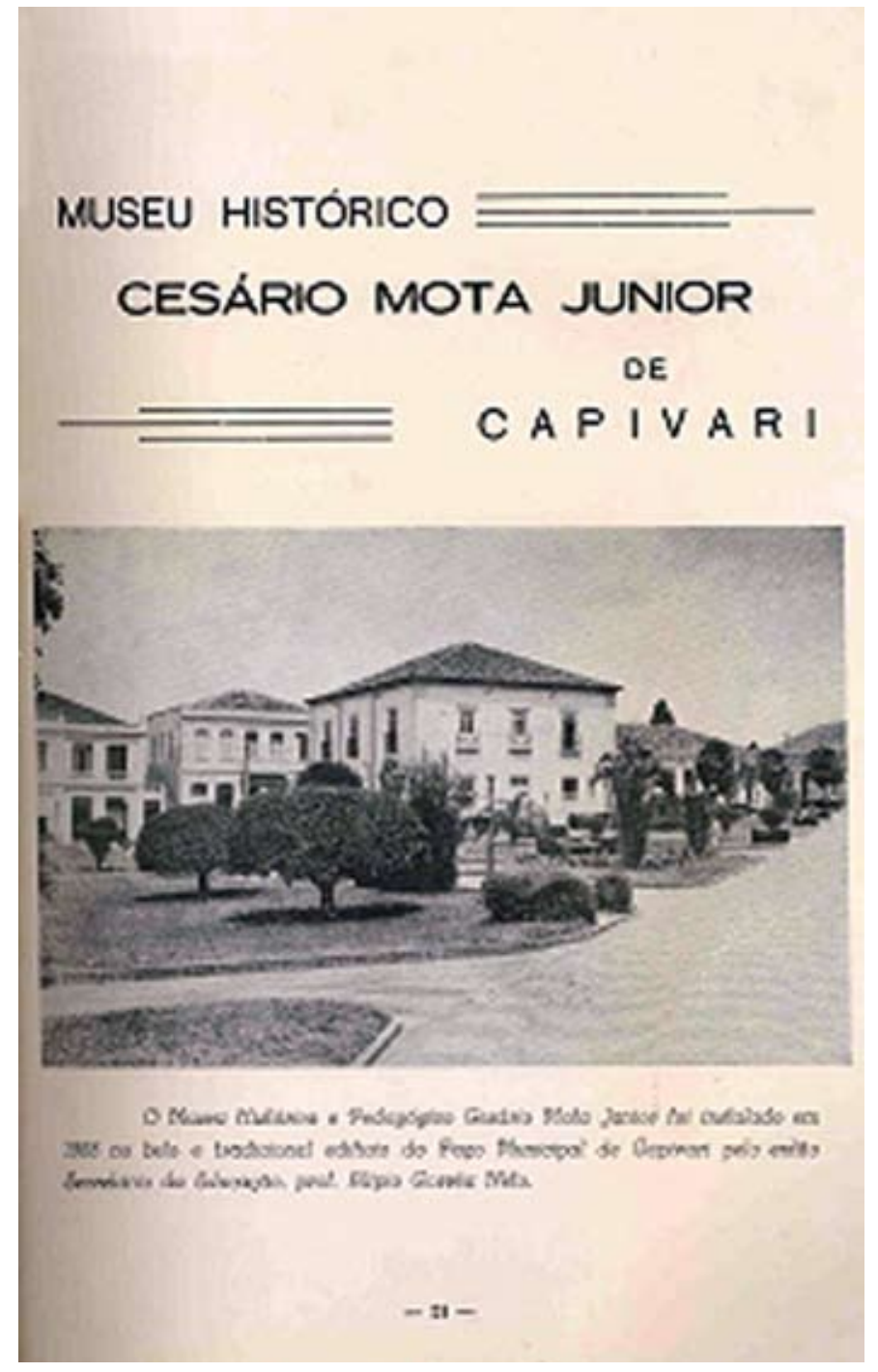

Figura 2 - "O MHP Cesário Mota Júnior foi instalado em 1958 no belo e tradicional edifício do Paço Municipal de Capivari pelo então Secretário de Educação, Prof. Alípio Corrêa Neto". In: Secretaria de Educação do Estado de São Paulo. Museus e monumentos históricos de São Paulo, 1960. 
14. Como bem analisa Souza (1998, p. 134-135).

15 J. Love (1982, p. 168).
Em grande parte das cidades onde Stein implantou os museus, iá teriam sido instalados, durante a Primeira República, os primeiros grupos escolares, todos eles com nomes de destacados personagens históricos estaduais ou da região:

Nos grupos escolares criados entre 1894 e 1910 (incluídas as escolas-modelos) foi perpetuada a memória dos mais eminentes políticos republicanos: Bernardino de Campos, Prudente de Morais, Jorge Tibiriçá, Rangel Pestana, Gabriel Prestes, José Alves Guimarães Junior, Cesário Motta, Alfredo Pujol, entre outros. Homens que ocuparam cargos de presidente do Estado, secretário do interior, senadores, deputados, presidentes de Câmaras Municipais, políticos locais, barões, coronéis e doutores. É a República imortalizada na memória coletiva pela lembrança de seus representantes máximos ${ }^{14}$.

Também com relação à composição de uma lista de patronos para sua rede de museus, Stein contou com o apoio do IHGSP. Ao longo da década de 1960, sua presença na Comissão da Revista do IHGSP permitiu participar da seleção dos temas e dos conteúdos dos textos produzidos pelos sócioscolaboradores da capital e pelos correspondentes das cidades do interior. A proximidade com o volume de estudos históricos publicados pode ter servido como um roteiro histórico importante na escolha de cidades e de patronos, para o embasamento de seu plano de criação e assentamento de uma rede de museus públicos.

O passo seguinte deste estudo foi analisar em que medida esse roteiro histórico pode ter, também, norteado uma determinada implantação dos museus no território geográfico de São Paulo. Consultaram-se alguns mapas do estado, do início do século, e neles puderam verificar-se alguns aspectos importantes, a partir da sobreposição das unidades museológicas (Figura 3).

Num primeiro momento, percebe-se uma malha extensa, ramificada, de unidades distribuídas por todo o território paulista. Depois, notamos que tal rede se assenta segundo algumas linhas predominantes, mas chegando a abranger a totalidade do Estado. Por fim, podemos ver que a rede de museus acaba por englobar dez zonas regionais do estado de São Paulo: o Vale do Paraíba, a Costa Sul, a Capital, a Central, a Mogiana, a Baixa Paulista, a Araraquarense, a Alta Paulista, a Alta Sorocabana e a Baixa Sorocabana ${ }^{15}$.

Outro ponto importante a considerar é a expressiva produção de biografias sobre os patronos, e de estudos sobre o histórico de origem das cidades onde estão instalados os MHP, publicados na Revista do IHGSP entre os anos 1894 a 1994 (cerca de 1.561 artigos). Tal fato identifica a existência de um ambiente que pode sugerir um passado histórico lou talvez tivesse mesmo a incumbência de fornecê-lo), sobre o qual poderia delinear-se a rede de museus. A profusão de textos publicados - e o interesse de Stein em valorizar e utilizar este material - indica o esforço empreendido por toda uma geração de escritores, sócios do IHGSP, colaboradores e servidores, na construção de um imaginário da história paulista. Este imaginário, além de ter servido diretamente à história e 


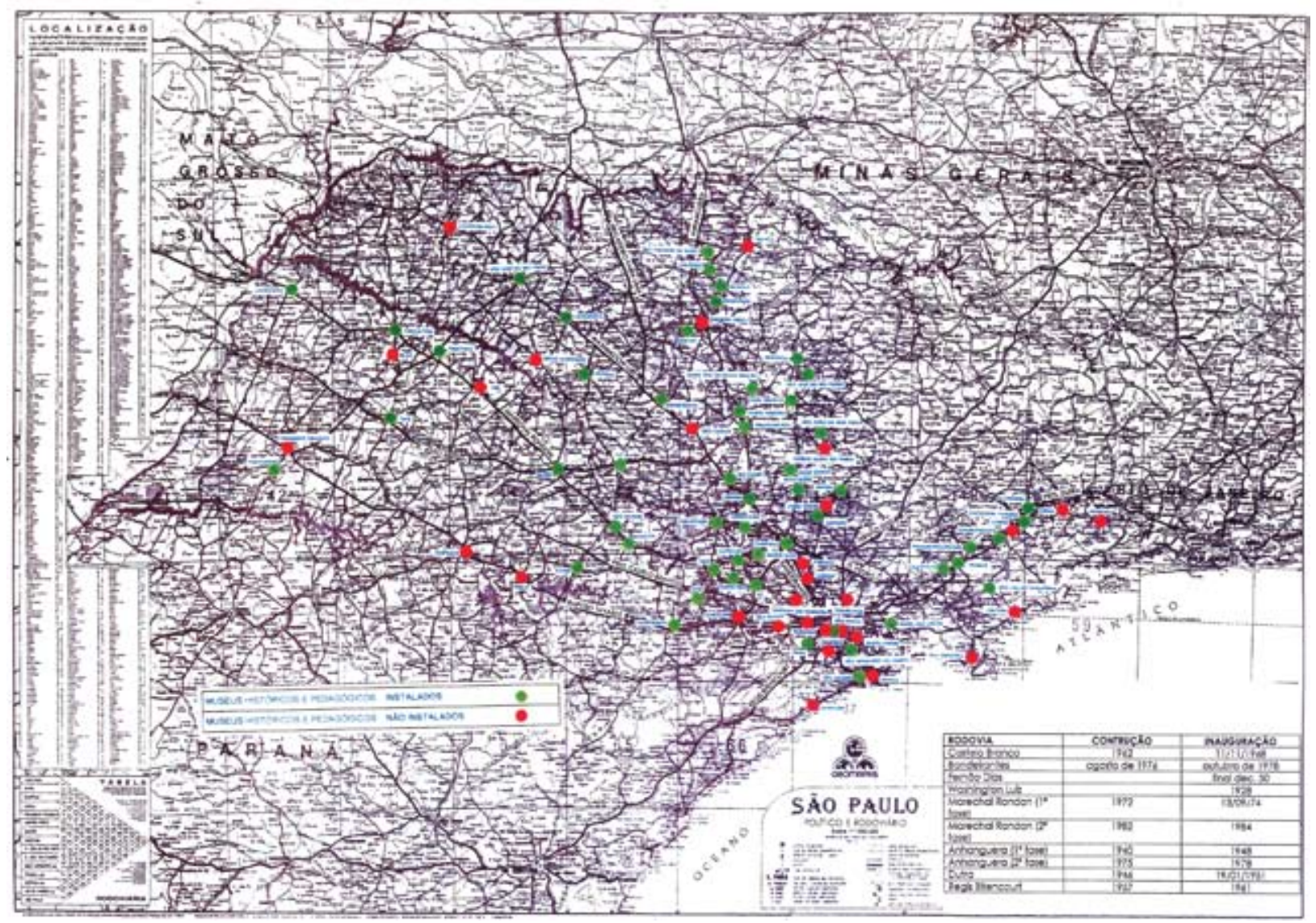

Figura 3 - Mapa elaborado para análise da localização da rede de MHP. Identifica museus instalados (em verde) e não instalados (em vermelho). Simona Misan, 2005.

à literatura ${ }^{16}$, como já é sabido, pôde, neste caso em particular, servir também à museologia.

Por uma identidade histórica

Os primeiros MHP foram designados à memória dos quatro primeiros presidentes republicanos civis e paulistas da primeira República (1890-1930): MHP Prudente de Morais (1894-1898), em Piracicaba; MHP Campos Salles (1898-1902), em Campinas; MHP Rodrigues Alves (1902-1906), em Guaratinguetá; e MHP Washington Luís (1926-1930), em Batatais. Por serem os primeiros e por constituírem eles próprios uma matriz da rede, deve ser destacada certa singularidade no que se refere ao tratamento que lhes foi dado. Além disso, uma análise mais atenta sobre o conjunto de seus acervos revela particularidades com relação ao conjunto dos demais museus da rede. 
17 A respeito do destaque dado ao período republicano, ver José Murilo de Carvalho (1998), em que o autor desenvolve uma análise aprofundada acerca do esforço de consolidação de celebrações e datas comemorativas, no Rio de Janeiro, na passagem dos séculos XIX e XX.

18 "Ora, além de ter surgido em uma sociedade profundamente desigual e hierarquizada, a República brasileira foi proclamada em um momento de intensa especulação financeira, causada pelas grandes emissões de dinheiro feitas pelo governo para atender às necessidades geradas pela abolição da escravidão. A febre especulativa atingiu de modo especial a capital do país, centro dos acontecimentos que levaram à República. [...] $\mathrm{O}$ espírito de especulação, de enriquecimento pessoal a todo custo, denunciado amplamente na imprensa, na tribuna, nos romances, dava ao novo regime uma marca incompatível com a virtude republicana $[\ldots]$ Simplesmente não havia preocupação com o público". Cf. José Murilo de Carvalho (1998, p. 29-30).

19. Museus e Institutos consultados em São Paulo: Museu Paulista, Museu Republicano Convenção de Itu, MHP Prudente de Morais, IHGSP, Centro de Ciências Letras e Artes, MHP Campos Salles, MHP Rodrigues Alves, MHP Washington Luís. No Rio de Janeiro: Museu da República e IHGB.

20. Foram eles: Arquivo do Museu Paulista (MP-USP), Arquivo Museu da República (MR-RJ), Arquivo Museu Republicano Convenção de Itu (MRCI-USP), Centro de Ciências Letras e Artes de Campinas (Acervo Campos Salles).
Os quatro museus foram criados com um duplo objetivo: preservar a memória dos presidentes paulistas e cultuar o período republicano ${ }^{17}$. De acordo com José Murilo de Carvalho (1998), a dificuldade de fixação e aceitação da construção de um imaginário republicano revelou o abismo entre uma elite dirigente - políticos, militares e intelectuais do novo regime - e o povo de uma maneira geral ${ }^{18}$. A instauração dos novos símbolos (os monumentos, o mito de Tiradentes, a bandeira republicana, a figura feminina, o hinol permitiria, exatamente, consolidar a participação do povo - ao menos na história - na transição do regime monárquico para o republicano. Assim, foram inúmeras as discussões não só acerca da eleição dos símbolos que deveriam perpetuar o novo regime, como também, das dificuldades do período em fixar heróis que tivessem penetração num imaginário coletivo.

Ao criar, em 1956, os MHP dedicados à memória dos quatro presidentes republicanos paulistas, Sólon Borges dos Reis, então há seis anos membro do IHGSP, parecia cumprir dupla missão: não somente procurava afirmar a participação do estado de São Paulo no imaginário republicano (sobretudo no da oligarquia paulista), bem como buscava reforçar a identidade do IHGSP, como guardião e leal depositário desta memória. Ao tentar perpetuar a participação política dos presidentes republicanos paulistas, o IHGSP procurava não somente fixar os seus símbolos no imaginário republicano, como reforçava seu papel, contrapondo-se ao Instituto Histórico e Geográfico Brasileiro (IHGB), no Rio de Janeiro, o primeiro e mais antigo dos Institutos Históricos e Geográficos brasileiros. Devemos considerar, entretanto, que perpetuar a memória da participação dos paulistas na República foi, desde cedo, uma vontade do Estado e precedeu a criação dos MHP. Uma das primeiras ações empreendidas nesse sentido foi a criação do Museu Republicano Convenção de ltu (MRCI), em 1923. Há, porém, diferenças entre o Museu Republicano e os primeiros MHP. O que os distingue é o fato de o primeiro museu privilegiar bem mais o episódio da Convenção de ltu, enquanto os demais pretenderam destacar, particularmente, a vida e a trajetória dos presidentes paulistas.

A criação dos MHP parecia, então, atender antigas reivindicações de representatividade de São Paulo no imaginário republicano. Outra particularidade a ser destacada, com relação a este primeiro conjunto de MHPs, é o fato de, além de disputarem seu quinhão no processo de construção da memória na República, os museus paulistas parecerem ainda, representar certas disputas entre antigos poderes das oligarquias regionais do estado em algumas cidades como Itu, Piracicaba, Campinas, Guaratinguetá e Batatais.

Além do Museu Republicano Convenção de ltu e dos MHP nas cidades de Piracicaba, Campinas, Guaratinguetá e Batatais, foi verificada a existência de outros possíveis núcleos de preservação da memória dos presidentes paulistas, em São Paulo e no Rio de Janeiro ${ }^{19}$. A análise comparativa das informações revelou a existência de peças atribuídas aos presidentes em todos os arquivos pesquisados ${ }^{20}$, demonstrando existir, desde a época de suas fundações, uma luta velada pela consolidação de um imaginário em que ambas as cidades, 
politicamente atuantes na instauração da República, buscam pleitear sua legitimidade. Tal legitimidade estaria garantida na visibilidade oferecida pelos museus e arquivos, seja na conservação ou na exposição dos referidos acervos.

Dessa maneira podemos concluir que os responsáveis pela criação, definição, formação e guarda de acervos dos MHP puderam implantar uma questão tão cara ao IHGSP e que dizia respeito à identidade do Instituto e também à do Governo do Estado. A criação de MHP foi uma iniciativa que contou com o intenso apoio deste último, de modo a permitir-he que, por meio de ações no campo da preservação da memória, afirmasse sua hegemonia política.

Por uma identidade geográfica

O estudo do mapa de implantação dos MHP revelou, num primeiro momento, que, além das condicionantes históricas, a localização geográfica determinou o posicionamento dos diversos museus no território paulista. Com base nessa premissa, aprofundamos as investigações da implantação dos museus no que tange à análise da geografia do Estado. Para tanto, foram levantados alguns mapas, como o das linhas ferroviárias (1903) e o das estradas rodoviárias (1977). O objetivo foi analisar os acessos, revelados por estes mapas, para o interior do estado de São Paulo e verificar as semelhanças e diferenças com o traçado de implantação dos MHP. Também procuramos analisar tanto o avanço das vias ferroviárias, quanto das rodoviárias, pelo interior do estado, a partir do início do século XX até meados da década de 1970, data em que toda a rede já se encontrava implantada (Figuras 4 e 5).

Comparando-se a localização dos 79 MHP com as linhas ferroviárias (em 1903 e 1977) e com as estradas rodoviárias (entre as décadas de 1950 e 1970) existentes e em construção no estado de São Paulo, é possível estabelecer alguns parâmetros explicativos de caráter geográfico. A análise comparativa dos mapas revela a presença de traçados comuns, que se sobrepõem com o passar dos anos, e também a substituição das linhas ferroviárias pelas estradas rodoviárias. Percebe-se a predominância de certos percursos geográficos, importantes na história estadual, que se expandem de forma ramificada, partindo da capital rumo ao norte, ao sul e, principalmente, ao centro-oeste do estado.

A cronologia da implantação das redes ferroviárias, ao longo das primeiras décadas do século XX, revela o enorme empenho no avanço da ocupação territorial para o interior do estado. A primeira delas, a linha ferroviária Santos-Jundiaí, teve início em 1867. Em seguida, foi criada a Companhia Paulista de Estradas de Ferro, inaugurada em 1872. Nessa mesma década, é inaugurada a Mogiana, que alcançou, em 1877, a cidade de Franca. A Paulista continuava sua expansão, ligando os principais povoamentos no interior do estado. Em 1875, chegou a Santa Bárbara; em seguida, a Limeira e Rio Claro (1876), a Araras (1877), a Pirassununga (1878), e a Porto Ferreira (1880). 


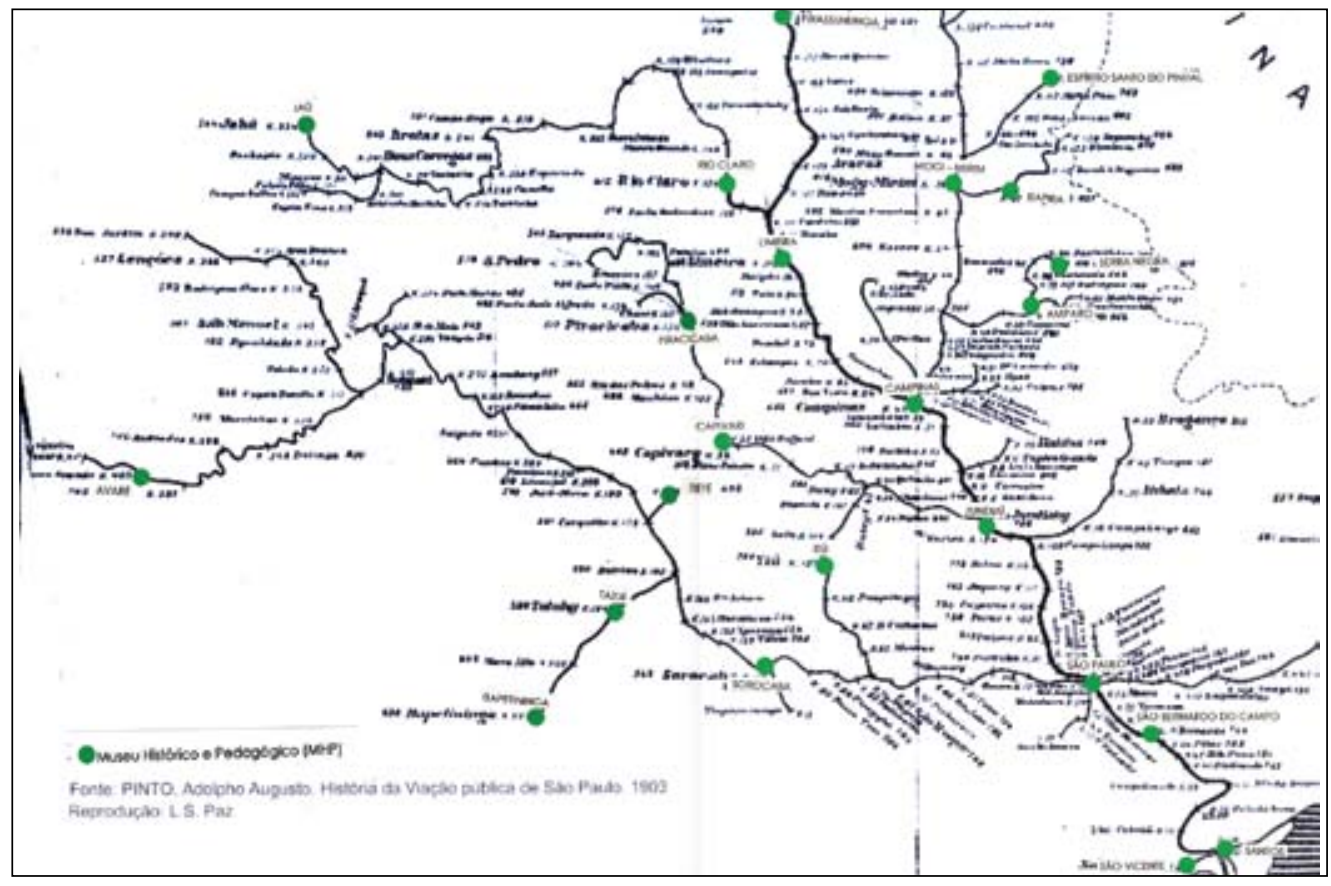

Figura 4 - Localização dos MHP sobre mapa da rede ferroviária em 1903. In: A. A. PINTO. História da viação pública de São Paulo. São Paulo: Livraria Vannorden, 1902.

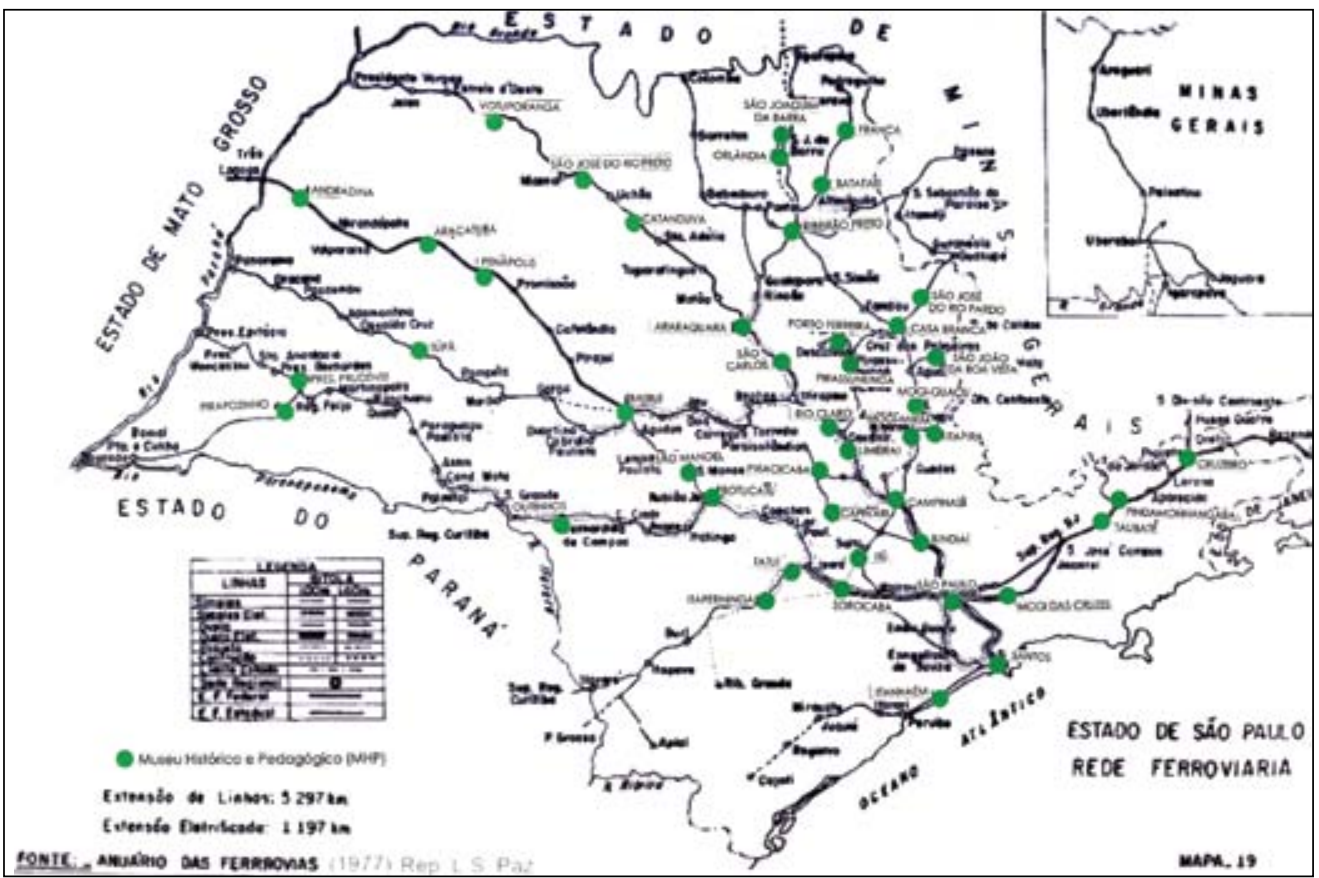

Figura 5 - Localização dos MHP sobre mapa da rede ferroviária em 1977. In: A. A. PINTO. História da viação pública de São Paulo. São Paulo: Livraria Vannorden, 1902. 
No mapa da rede ferroviária, em 1903, podem identificar-se muitas das cidades que, nas décadas de 1950 a 1970, viriam a abrigar unidades dos MHP: Presidente Prudente, Ourinhos, Catanduva, Rio Preto, Sorocaba, Tatuí, Itu, Capivari, Campinas, Amparo, Itapira, Mogi Mirim, Araras, Limeira, Piracicaba, Rio Claro, Pirassununga, Avaré e Jaú. Mas foram as estradas rodoviárias - como a Washington Luís (1928), a Anhangüera (1940-48), a Fernão Dias (1950), a Dutra (1946-51) e a Raposo Tavares (c. 1954), entre outras - que tornaram possivel alcançar as cidades mais distantes do estado, onde seriam instaladas as últimas unidades da rede dos museus.

$\bigcirc$ progresso na construção das linhas ferroviárias e o gradativo surgimento das estradas rodoviárias - somados a fatores econômicos, pois algumas dessas cidades são importantes pólos de produção e exportação de produtos agropecuários - propiciaram o enorme crescimento demográfico. $\bigcirc$ aumento da população, somado ao da migração de mão-de-obra do campo para os núcleos urbanos, resultou num vertiginoso processo de urbanização das cidades, principalmente nas décadas de 1950 e 1960. Devemos destacar que foi justamente esse o período em que foi instalada a maior parte dos museus, e foram formados os acervos desses museus, segundo apontam as listagens de doações e os acervos pesquisados nos arquivos Vinício Stein Campos (VSC) e Museu Histórico Pedagógico (MHP), no Departamento de Museus e Arquivos, da Secretaria de Estado da Cultura (Dema-SEC).

Além dos mapas de localização dos museus, das linhas ferroviárias e das estradas rodoviárias, neste estudo comparativo incluímos um mapa muito particular, encontrado em dois acervos pesquisados, o do MHP Bernardino de Campos (Amparo) e o do MHP Prudente de Morais (Piracicaba) (Figura 6). Nele, vemos os caminhos trilhados, durante a Revolução de 1932, pelas tropas paulistas e pelas frentes de combate que passavam por cidades do interior do estado em direção, principalmente, às fronteiras de Minas Gerais e do Rio de Janeiro ${ }^{21}$. Novamente se percebe a presença de cidades já identificadas em outros mapas e, em especial, os traçados das linhas ferroviárias e a localização $\operatorname{dos} M H P$.

As cidades presentes nos mapas analisados têm, portanto, certa singularidade na relação dos aspectos históricos e geográficos. Com relação à importância histórica do conjunto das cidades, podemos destacar que, nessa vasta geografia delineada pela rede de MHP, podemos percorrer o caminho das Bandeiras, as passagens de D.Pedro I, de D.Pedro II, a proliferação de grupos escolares, os importantes encontros políticos e convenções que antecederam a proclamação da República ${ }^{22}$, as cidades-sede dos institutos históricos e geográficos e do Partido Republicano Paulista, os focos de resistência da Revolução Constitucionalista de 1932 e, por fim, o avanço da economia agropecuária e industrial.

Partindo dessas considerações, pode-se arriscar que, talvez, o possível planejamento elaborado por Stein para a implantação das diversas unidades dos MHP no estado possa ter levado em conta a importância de enlaçar os
21. A respeito do tema "cartografia imaginária” da Revolução de 32 , ver Waldo Cesar (2002).

22. Entre os quais os ocorridos em Itu, em 1873, e em São José do Rio Pardo, em 1889. 
23. Cf. Lourenço Luis Lacombe em co-autoria com A. Cotrim (1987).

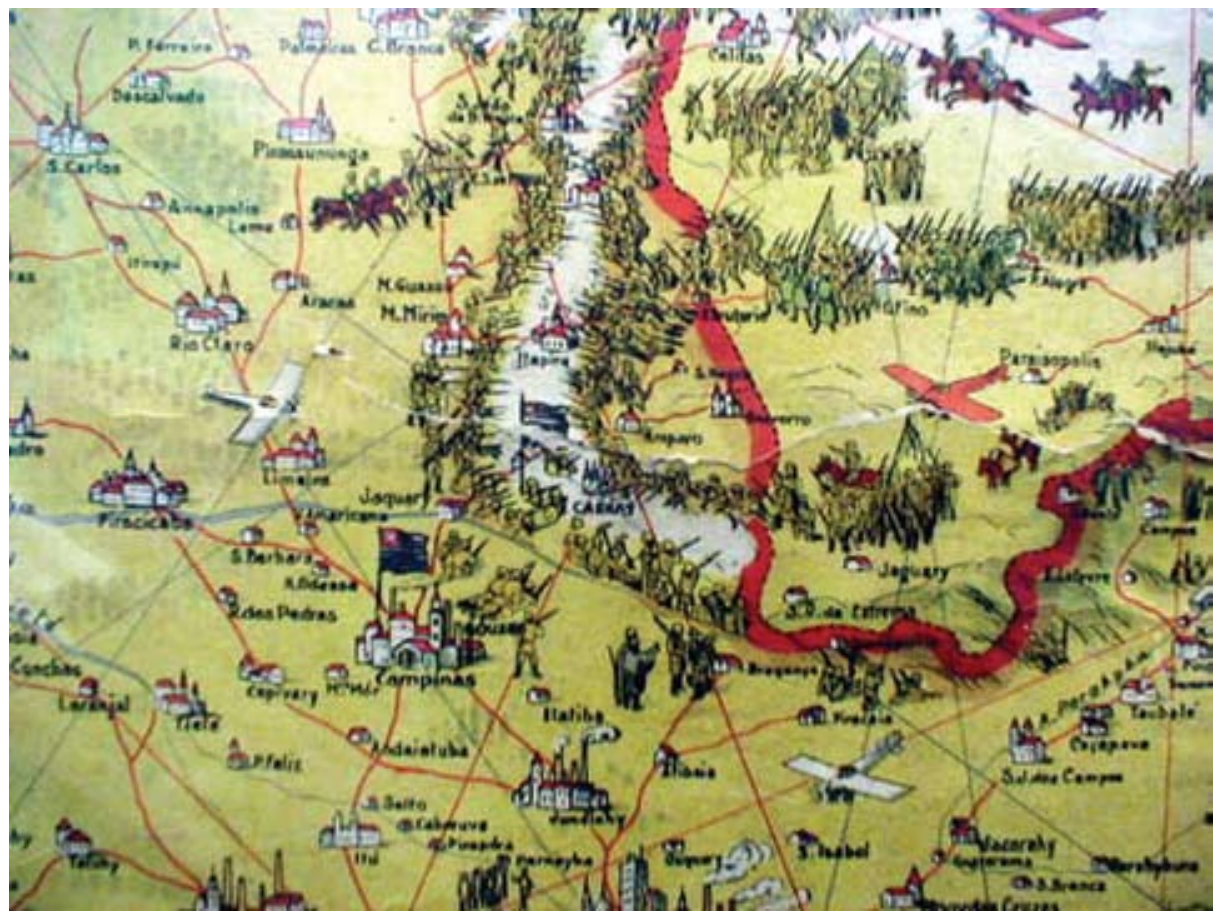

Figura 6 - Detalhe de mapa com a localização das tropas constitucionalistas no estado de São Paulo. Acervo do MHP Prudente de Morais, Piracicaba, São Paulo. Fotografia de Simona Misan, 2005.

museus com a cartografia histórica do estado. Dessa forma, pode-se concluir que o caráter histórico pretendido à rede de museus proposta por Stein, além de perpetuar a memória de seus patronos, também se relaciona à história da ocupação geográfica do estado, em especial à das regiões onde os museus estão sediados. Essa, talvez, seja a razão que explique a existência de um grande número de coleções de zoologia, botânica, taxidermia, geologia, arqueologia e antropologia presentes em grande parte dos acervos dos MHP. Tais museus, então, em certa medida, também tiveram uma outra incumbência: a de preservar as características naturais e culturais das diferentes localizações geográficas das respectivas cidades que integraram a rede de museus.

Por uma identidade institucional

"O que ficou representa o passado, um passado que pode ser
enriquecido de verdade e permanência." 23

Lourenço Luis Lacombe

Ao longo de sua atuação, Vinício Stein correspondeu-se com diversos prefeitos, professores, colaboradores do $I H G S P$, entre outras autoridades das 
cidades onde implantou os MHP. O conjunto de sua correspondência foi reunido em 27 volumes, organizados por cidades, atualmente sob a guarda do DemaSEC (Arquivo VSC). Uma pesquisa mais aprofundada à correspondência de Stein revelou o grau de isolamento em que ele atuou, no que diz respeito ao contato com demais diretores de museus históricos, principalmente os paulistas. Não foram encontradas cartas entre Stein e diretores de outros museus históricos de São Paulo e do país, com exceção de Lourenço Luiz Lacombe, diretor 11967 1990) do Museu Imperial em Petrópolis, no Rio de Janeiro.

Na correspondência com professores-diretores das unidades de MHP, Stein, sempre que podia, solicitava a realização de visitas técnicas ao Museu Imperial. Com base nesses documentos, poderíamos concluir que o Museu Imperial foi, para Vinício Stein, uma referência importante. Mas, considerando a distância da cidade e a especificidade de seu acervo (todo ele voltado à preservação do ambiente em que vivia a família imperial), quais seriam as razões que levaram Stein a considerar o Museu Imperial um museu-modelo para os MHP?

Antes de nos aprofundarmos nessa questão, vale salientar ser surpreendente o fato de que, de um lado, o interesse de Vinício Stein tenha se voltado para estabelecer intercâmbio com o Museu Imperial. Por outro, é notória a ausência de documentação com referências ao Museu Paulista ou ao Arquivo do Estado, instituições que, conforme citado por Stein no Regulamento dos MHP (1957) 24, poderiam auxiliar na empreitada de instalação dos museus. Todavia, em Elementos de Museologia, obra planificada em onze volumes, editada pela Secretaria de Esportes e Turismo de São Paulo, na década de 1970, de autoria de Vinício Stein, um desenho da maquete do Museu Paulista ilustra a capa do terceiro volume (Figura 7), e o acervo da instituição é, aí, detalhadamente descrito.

Talvez a falta de correspondência com o Museu Paulista - o maior acervo representativo da história paulista dos períodos colonial, imperial e republicano - possa ser explicada por um fator: a presença de Mário Neme na direção da instituição (1960-1973), justamente no período em que a maior parte da rede de MHP foi instalada.

Historiador e diretor de museu histórico público em São Paulo, Mário Neme foi o primeiro, e o único ${ }^{25}$ que se opôs oficialmente ao programa de implantação da rede de MHP no Estado. Discordava expressamente do programa de Stein, sem, contudo, dirigir-se nominalmente a ele. Também se opunha à Secretaria de Educação e ao próprio governo do estado, por amparar e subsidiar a iniciativa, em sua opinião, plenamente equivocada ${ }^{26}$.

A crítica empreendida por Mário Neme, em artigo publicado nos Anais do Museu Paulista, em 196427, é um dos raros registros, senão o único, que analisa a atitude empreendedora do estado na criação dos MHP, num momento em que grande parte dos museus da rede estava sendo instalada. Mas mesmo considerando o fato da presença de Mário Neme na direção do Museu Paulista, é surpreendente a ausência de contato com dirigentes do mais antigo museu histórico do estado. Também não há sequer menção a Affonso Taunay,
24. Os Museus contarão, para execução de seu programa cultural, com a colaboração do Departamento de Educação, do Museu Paulista e do Departamento do Arquivo do Estado. Ver Vinício Stein Campos (1960, p. 61).

25. O Museu Paulista, até 1963, esteve sob a guarda e administração do Governo do Estado de São Paulo. A partir dessa data, passou à Universidade de São Paulo.

26. Ver Mário Neme (1964, p. 17).

27. Neste artigo Mário Neme opunha-se veementemente à "iniciativa do Estado de pulverização dos museus" que em sua opinião apenas "reforçava seu caráter de dispersão". Cf. Mário Neme (1964, p.7-62). 


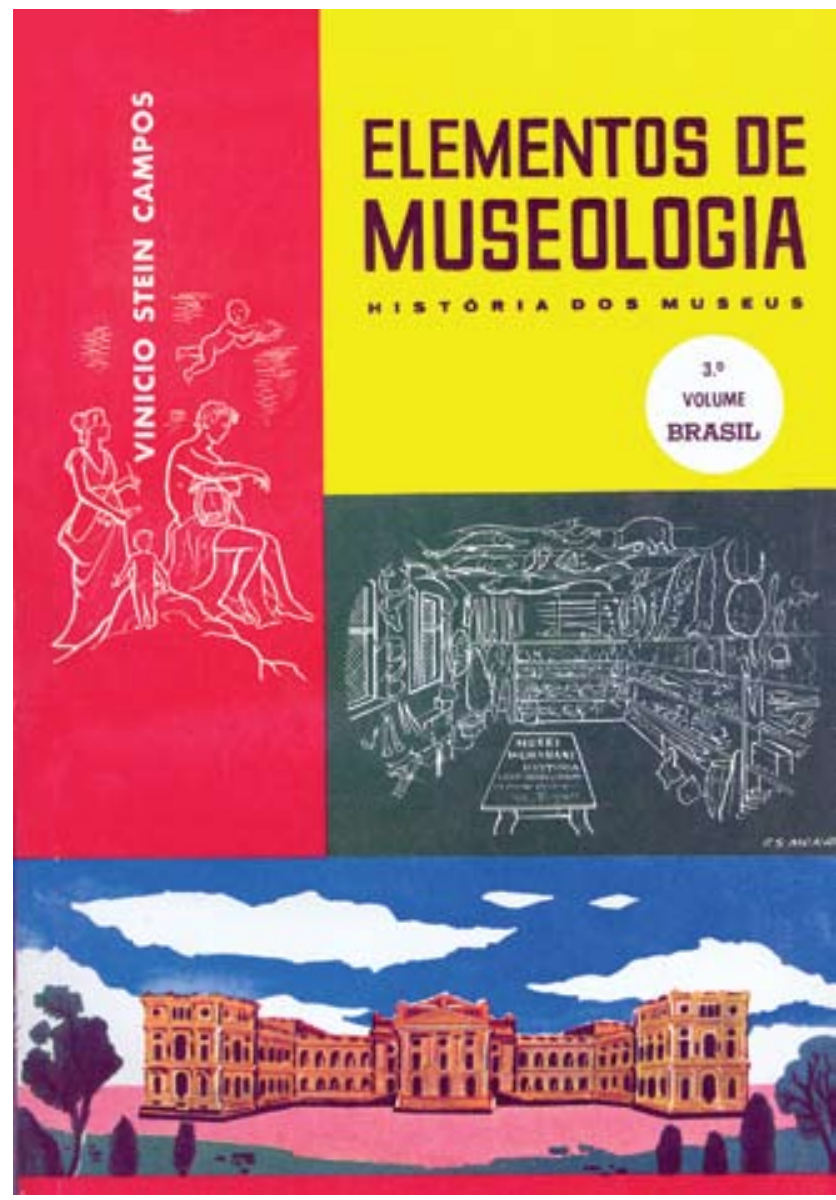

Figura 7 - Capa do volume III do livro Elementos de museologia. História dos museus - Brasil, de Vinício Stein Campos, ca. 1970. Reprodução de Simona Misan, 2005.
28. Carta de Vinício Stein Campos, enviada ao Museu Imperial, Petrópolis, em 29.12.1969. Arquivo do Setor Administrativo Museu Imperial, Protocolo 42.

29. Carta de L. L. Lacombe, enviada a Vinício Stein Campos, em 7.1.1970. Arquivo Setor Administrativo Museu Imperial, Protocolo 42. membro de destacada atuação no IHGSP e segundo diretor do Museu Paulista (1917-1945).

Para Stein, eram os museus do estado do Rio de Janeiro, em especial - Museu Nacional (1818) e o Museu Imperial (1943), ambos sediados em antigas residências da família imperial (Palácio da Quinta da Boa Vista e Palácio de Petrópolis), que mais o interessavam.

Na correspondência analisada no Arquivo VSC (Dema-SEC), no volume Cidade de Tupã (MHP Índia Vanuíre), consta uma carta em que Stein solicita ao diretor do Museu Imperial, Lourenço L. Lacombe, estágio para a Profa . Maria de Lourdes Corrêa Manzano, com a justificativa de que o contato com o museu "a colocaria ao corrente da técnica nele adotada quanto à classificação, arrumação, catalogação, organização, etc, a fim de que possa levar para o Museu de Tupã o precioso concurso dessas informações, de indiscutível valor para a sua funcionalidade" 28 . Fato que pôde ser comprovado, pois foi encontrado, nos arquivos do Setor Administrativo do Museu Imperial, documento de registro da visita da professora, conduzida pessoalmente por seu diretor ${ }^{29}$ (Figuras 08 e 09). 
Figura 8 - Carta de Vinício Stein Campos enviada a Lourenço Luiz Lacombe, diretor do Museu Imperial, 29 de dezembro de 1969. Arquivo Vinício Stein Campos, vol. Cidade de Tupã, DEMA-SEC/SP, São Paulo (SP). Reprodução de Simona Misan, 2005.

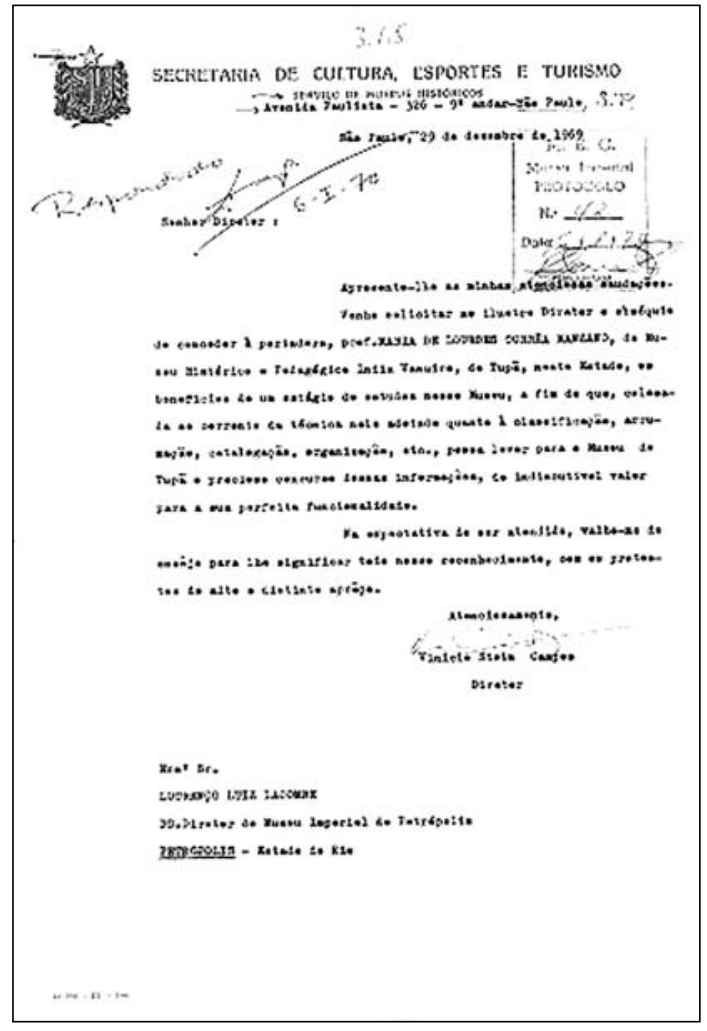

Figura 9 - Cartão postal no qual Vinício Stein Campos agradece a Luiz Lacombe a atenção dada à diretora do MHP Índia Vanuíre (Tupã, São Paulo) em visita, em 2 de fevereiro de 1970, ao Museu Imperial, Petrópolis. Arquivo do Museu Imperial, Petrópolis (RJ). Reprodução de Simona Misan, 2005. 
30. Cf. Simona Misan (2005, p. 111-112).

31. Cf. Edgar Sussekind (1946, p. 3).

32. Cf. Venâncio Filho (1941, p. 142)

33. Ver Jonathas Serrano (1935).

34. A respeito da escolha dos patronos dos MHP, sua museografia e a indicação do que seus acervos deveriam constituir, e o que de fato foi reunido, ver Simona Misan (2005, p.32-40; p.125134).
Além de servir, para Stein, como exemplo da prática da museologia, - Museu Imperial, nas décadas de 1940 e 1950, congregou importantes educadores e esteve à frente das principais discussões na relação entre museu e sociedade. Devemos salientar que esse era tema que já vinha sendo tratado em estudos e publicações de grande parte dos intelectuais da educação. Nas décadas de 1930 e 1940, encontramos uma significante bibliografia a respeito de novos meios no ensino, onde o papel do museu é quase sempre analisado, o que demonstra ser tema de interesse dos escolanovistas ou de simpatizantes dos métodos da Pedagogia Nova. Alguns dos autores são Fernando de Azevedo (Reforma do ensino no Distrito Federal, 1929; Novos caminhos e novos fins, 1931; A cultura brasileira, 1941), Jonathas Serrano (Como se ensina história, 1935), Everardo Backheuser (A técnica da pedagogia moderna: teoria e prática da Escola Nova, 1934), Francisco Venâncio Filho (A Educação e seu aparelhamento moderno, 1941; o mesmo autor, em co-autoria com Serrano, Cinema e educação, 1930; A função educadora dos museus, 1939), RoquettePinto (A história natural dos pequeninos, 1925; Seixos rolados, 1927), Edgar Sussekind (Ensino e cultura, 1940; A extensão cultural dos museus, 1946) ${ }^{30}$.

Nas discussões promovidas na época no campo da educação lideradas pelos educadores Edgar Sussekind ${ }^{31}$, Venâncio Filho ${ }^{32}$, Jonathas Serrano ${ }^{33}$, entre outros, pode-se constatar que o Museu Imperial foi uma referência importante no período, pois não deixou de abrigar e promover o ideário proposto pelos escolanovistas quanto à função educadora dos museus na sociedade. Assim que o Estado adquiriv o Palácio Imperial para sediar o museu, foi realizada, na cidade de Petrópolis, por iniciativa do Instituto de Estudos Brasileiros, a conferência A função educadora dos museus. $O$ evento contou com a participação de expoentes do Movimento da Escola Nova, entre eles, Venâncio Filho, $\mathrm{H}$. Leão Teixeira, Jonathas Serrano e também Alcindo Sodré, que logo em seguida viria a ser o primeiro diretor do Museu Imperial. Durante décadas, os efeitos da influência das diretrizes dos educadores escolanovistas continuaram fortemente presentes nas atividades do museu. Como exemplo, podemos citar a realização de sessões de cinema educativo, dirigidas aos escolares da época (Figura 10).

Alguns aspectos interessantes do que possa ter representado o Museu Imperial para o conceito que Stein tinha sobre museologia foram revelados por uma investigação mais aprofundada. Num primeiro momento, o interesse de Stein parecia referir-se ao conteúdo do acervo, todo ele representando o ambiente residencial do patrono D.Pedro II. Num segundo momento, seu interesse detém-se na organização expositiva das peças, todas elas dispostas como se fosse uma legítima casa histórica ${ }^{34}$. Essas são razões que tornariam o Museu Imperial modelar para o que pode ser entendido como proposta museológica dos MHP. A predileção pelo Museu Imperial pode ter-se apoiado, porém, em razões bem menos evidentes, mas que possam ter sido fundamentais para Stein. E quais seriam elas? Na relação entre D. Pedro II, patrono do Museu Imperial, e a cidade de Petrópolis, havia algo velado que merecia ser analisado, permitindo entender as razões que levaram Stein à valorização do culto a D.Pedro II. 


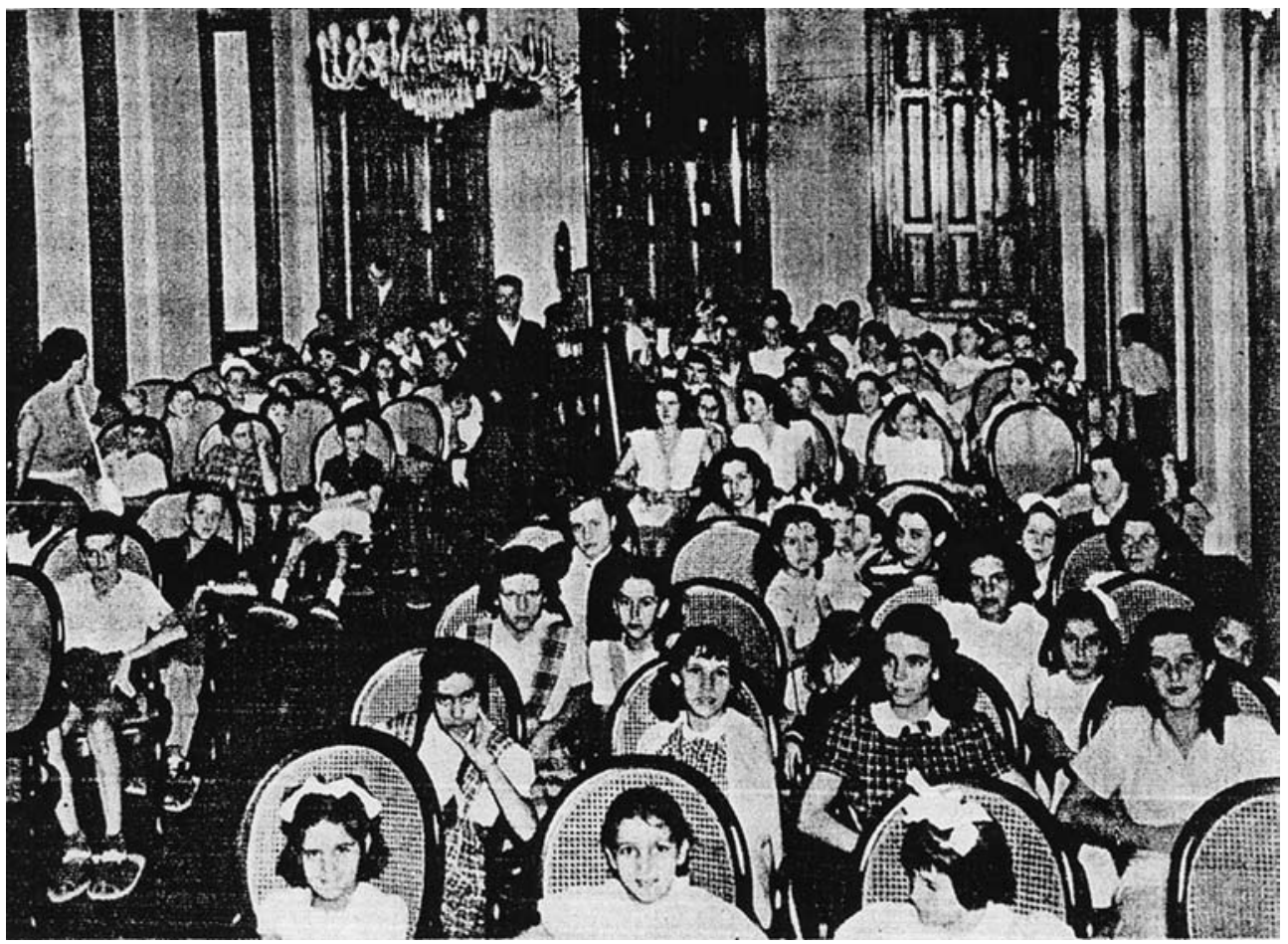

Figura 10 - Sessão de cinema educativo no Museu Imperial, Petrópolis, ca. 1943. Arquivo do Museu Imperial, Petrópolis (RJ).

Um estudo mais aprofundado dos arquivos e da biblioteca do museu, bem como aos monumentos históricos da cidade, revelou informações importantes, que nortearam boa parte das reflexões e conclusões alcançadas neste trabalho. Também uma análise mais detalhada da importância que o imperador e patrono do museu poderia representar para Vinício Stein permitiu uma compreensão mais ampla do assunto.

D.Pedro Il governou o país por longos cinqüenta anos. Sua figura é valorizada pelo interesse demonstrado pelo estudo das ciências, pela educação e por novas tecnologias. Em seu governo, foram vários os benefícios promovidos: assinou o Decreto que criou o Selo Postal nos Correios Brasileiros (1842), inaugurou a Estrada Indústria União, ligando Petrópolis ao Rio de Janeiro (1861) e, após contato com Graham Bell na Exposição Universal de Filadélfia, introduziu o telefone no Brasil (1876). Participou e financiou o surgimento de instituições dedicadas ao estudo e preservação da história, foi fundador, mantenedor e presidente honorário do $1 H G B$, criado em 1838, no Rio de Janeiro.

O fato de D.Pedro II ter sido o fundador do IHGB poderia, de alguma maneira, estar relacionado à particular predileção de Stein pelo Museu Imperial. E de fato estava, pois Stein, membro do IHGSP, não poderia deixar de prestar seu tributo a esse personagem histórico de central importância, patrono do primeiro Instituto, e, portanto, de todos os demais do país. Ao prestigiar o Museu Imperial, 
35. Cf. Solange de Sampaio Godoy (1989, p. 5).

36. Cf. P. Ferreira de Souza Lima (2001, p. 5).

37. Príncipe do Grão-Pará, sucessor imediato da princesa Isabel, nascido no Palácio da Princesa, em Petrópolis, em 1875 e falecido em 1940. Inscrição na lápide na Catedral de São Pedro de Alcântara, Petrópolis.

38. O IHGSP, ao qual Vinício Stein era filiado, participou na organização do traslado dos despojos da imperatriz Maria Leopoldina e de D. Pedro I, instalados, nos anos 1970 , na cripta do Museu Paulista. Também foram vários os artigos publicados na Revista do IHGSP a respeito do estudo e da localização de despojos de bandeirantes, padres e personagens históricos.
Stein, de certa maneira reforçava sua devoção ao patrono do IHGB, ao enfatizar uma linha de pensamento, da museologia no Brasil, tendente à valorização de heróis e de acontecimentos históricos, como a defendida por Gustavo Barroso (1 888-1959), diretor do Museu Histórico Naciona|35. De outra, tomava o Museu Imperial, antiga residência de veraneio de D.Pedro II, e a cidade de Petrópolis, como exemplo fundamental na relação do binômio patrono e cidade, conforme a concepção dada à implantação da rede de MHP. Além do mais, a longa direção de Lacombe (1967-1990) no Museu Imperial, em parte simultânea ao período de implantação dos MHP (1956-1973), garantiu continuidade à concepção museográfica original, orientada por Gustavo Barroso, tal qual estabelecida em 1940, quando este fora solicitado para organizar o museu recém-criado. Quanto à cidade de Petrópolis, além de sediar o Palácio Imperial, constituiu-se em sede secundária da corte durante o período imperial e, mesmo após a proclamação da República, continuou a abrigar sucessores da família imperial até a década de 197036. A respeito de suas construções, a Catedral de São Pedro de Alcântara destaca-se como um dos principais monumentos arquitetônicos de Petrópolis. Em estilo gótico, com notável conjunto de mobília sacra, teve sua construção iniciada em 1876, a pedido da Princesa Isabel. Concluída em 1925, constituiu-se em importante edifício histórico, pois além da singularidade da arquitetura que a destaca na paisagem, a catedral abriga em sua cripta os restos mortais da família imperial. Nela estão, desde 1939 (data da inumação), os restos mortais de D. Pedro II e da Imperatriz Tereza Cristina.

Nesse mesmo ano (1939), muito provavelmente em decorrência desse importante acontecimento, é publicado o decreto que criou o Museu Imperial, para celebrar a memória do Imperador, que jaz para sempre na cidade de Petrópolis. Mais tarde, a cripta abrigaria os despojos do restante da família imperial: os da princesa Isabel e do conde D'Eu (1971) e os de D. Pedro de Orleans e Braganç $\mathrm{a}^{37}$ e da princesa Elisabeth Adelaide Leopoldina de Orleans e Bragança (1990).

Todos esses fatores levaram a considerar a importância e o significado que a cidade de Petrópolis teve para Stein, não só por todas as razões mencionadas, mas, principalmente, por abrigar os despojos mortais de D. Pedro Il e da família imperial, traduzindo simbolicamente o conceito de museu como local depositário de verdadeiros testemunhos históricos ${ }^{38}$. Trata-se de um exemplo claro (talvez o melhor que Stein encontrou no Brasil), para poder exemplificar a profunda integração entre museu e cidade, servindo, de modelo à sua proposta de implantação dos MHP.

A indicação do Museu Imperial como instituição de referência coloca em evidência também o fato de o atual museu ter sido uma antiga e legítima casa histórica. Uma pesquisa mais aprofundada, porém, do modo como se deu a formação do acervo do Museu Imperial revela informações surpreendentes. Do exposto no museu, apenas o relógio, localizado no saguão de entrada, pertenceu à antiga residência quando D. Pedro ll e sua família lá estiveram. Demais objetos, que comporiam o cenário da vida doméstica da família imperial, foram gradativamente adquiridos, seguindo a descrição e a maior aproximação 
possível a antigos inventários, em oportunidades de leilões realizados nas décadas de 1940, 1950, 1960, especialmente no Rio de Janeiro. A aquisição de objetos que pudessem figurar o modo de vida da família imperial foi, à época, uma prática incentivada e financiada pelo Governo do Estado, com particular dedicação de Getúlio Vargas ${ }^{39}$.

$\bigcirc$ fato de o museu ter sua sede em uma construção histórica também era importante, pois Stein procurava priorizar a instalação dos MHP em construções onde nasceram ou viveram os patronos dos museus. Para tanto, muitas vezes recorria ao Conselho de Defesa do Patrimônio Histórico, Artístico, Arqueológico e Turístico (Condephaat), de que foi membro conselheiro (1 967-1975), na tentativa, em grande parte bem sucedida, de obter o tombamento do edifício para em seguida instalar o museu ${ }^{40}$. Com o apoio do Governo do Estado, procurava legitimar antigas construções em casas históricas. Dessa maneira, além de procurar garantir a preservação do edifício enquanto arquitetura, Stein buscava instalar seus museus em construções que tivessem importância relevante para o Estado. Essa ação deve ser analisada de modo particular, ou seja, era uma via de mão dupla, pois, de um lado, afirmava a hegemonia do Estado em atestar a "historicidade" de seus edifícios históricos, e, por outro, conseguia o apoio do próprio Estado para a implantação de seus museus históricos naquilo que considerava como legítimas casas históricas. Mas o fato de obter o tombamento e a autorização para uso do imóvel não o restringia em sua empreitada, pois, caso não fosse possível ou a espera fosse demasiadamente longa, outro local, cedido provisoriamente pela Prefeitura ou pela Secretaria de Educação da cidade, poderia abrigar, ao menos, o início do surgimento do museu, como ocorreu com o museu de Mogi Guaçu (Figura 11 ).

Devemos salientar que a relação de escolha entre o patrono e a cidade-sede para a instalação dos museus poderia variar segundo circunstâncias. Alguns exemplos analisados demonstram que umas cidades foram escolhidas por ser local de nascimento dos patronos; em outras, o personagem passou por lá em atividade política; em ainda outras, é a cidade que se destaca como importante marco geográfico. Outros exemplos de cidades poderiam ter sido locais de marcos históricos e acontecimentos ligados aos períodos Colonial, Imperial ou Republicano, como a passagem de tropeiros, o deslocamento de combatentes da Revolução Constitucionalista de 1932; ou, simplesmente, o avanço do povoamento paulista rumo ao centro-oeste do estado.

Analisar em que medida a relação entre cidade e patrono (no caso, Petrópolis e D. Pedro II) possa ter influenciado na eleição do Museu Imperial como museu exemplar para os MHP é importante para compreender a construção, se assim podemos dizer, de um certo modelo de criação de museus históricos. Serve também para melhor entender diretrizes que possam ter orientado o exercício da museologia propagada por Stein, notadamente entre as décadas de 1950 a 1970.

Por uma "rede estadual" de museus
39. Sobre a história da formação do acervo do MI-RJ ver: Guia do Museu Imperial (1961); 1992).

40. Como exemplo, o pedido de tombamento para a Casa Major Ignácio de Camargo, em São Carlos, em 10. 7.1972. Processo SCET 08573 69, Arquivo VSC, São Carlos, Dema-SEC. 


\section{Museu se instalo}

\section{provisòriamente no Estádio}

Nesta semana que passou - Museu Histórlco e Pedagóglco "Sebastiāo José Pereira", de Mogi-Guacu, teve seu acervo mais uma vez transferldo para novas instalaçóes, no Estádio Municipal "Alexandre A. Camacho". All, nos salöes existentes sob a arquibancada, o setı Diretor, Prof, Jota Luiz Ferrelra Porto, val nermanecer por alguns meses, até que o local definitivo esteja pronto para receber as peças de nossa história, Será ele o amplo casarăo da praça Rui
Barbosa, oncie hoje funciona ca, duas casas de formação - Fórum, a mudar-se no ini- de nossa gente. Numa a tracio de 1974 para seu novo e magnifico prédio do morro do Ouro.

Lá no antigo sobrado o Museu terá um local realmente apropriado para exibir as centenas de pecas que possul, ficando junto à Biblioteca Municipal, que funcionará no alto. $\mathrm{O}$ antigo edificio do Clube Recreativo. assim, terá uma importante funçăo para a elevaçăo da cultura de nossa gente, abrigando Museu e Blbliote- dị̂̃o $e$ nossas ráizes; noutra os conhecimentos báslcos da humanidade, nos $11-$ vros, no alcance de nossos Jovens estudantes e de quantos queiram aproveitar-se do acervo em formaçăo.

Por sua vez, o prédio que vinha sendo ocupado até Sgto. Osvaldo Fernandes, será llberado para all ser instalada a agêncla da Calxa Econômica Federal, recentemente criada. agora pelo Museu, na rua

Figura 11 - Jornal O Guaçuano, Mogi-Guaçu, n. 969, 4.11.73. Arquivo Vinício Stein Campos, DEMA-SEC/SP, São Paulo (SP). Reprodução de Simona Misan, 2005.

No desenvolvimento do estudo dos MHP, constatamos que não poderíamos deixar de abordar os principais acontecimentos ocorridos no Brasil nas décadas de 1930 a 1970, no campo da cultura e da educação. A década de 1930 concentrou, na política e na cultura, importantes acontecimentos que influenciaram as décadas posteriores. Na nova fase do regime republicano, a questão da identidade do país estaria atrelada à idéia de integração e desenvolvimento nacional. A nova carta institucional de 1937, as leis trabalhistas, as reformas na educação, a criação de órgãos de defesa do patrimônio nacional, a criação de quatro museus federais e a arregimentação de intelectuais para atuar como servidores do Estado, em defesa da cultura e a serviço da organização social, foram fatores importantes a contribuir para a afirmação do papel centralizador do Estado.

Em contrapartida às oligarquias políticas, que buscaram valorizar afirmações muito mais ligadas a interesses regionais, o governo de Getúlio Vargas privilegiou a criação de um Estado Nacional, valorizando o emprego de esforços que promovessem ações integradoras. No campo da cultura e no da educação, promoveu ações que despertassem na sociedade o sentido de participação cívica, tornando-se ela própria agente das transformações. Nesse sentido, Gustavo Capanema, no Ministério da Educação e Saúde, foi um agente importante, ao congregar diversos colaboradores. Solicitou o apoio de 
educadores, arquitetos e urbanistas, poetas, artistas, e músicos que, direta ou indiretamente, ligaram-se às atividades de preservação empreendidas pelo Estado. Como exemplos importantes, podemos destacar a criação do Museu das Missões (1937) ${ }^{41}$, cujo restauro foi orientado por Lúcio Costa, e a criação do Serviço de Patrimônio Histórico e Artístico Nacional (1937), projeto de Mário de Andrade e direção de Rodrigo de Mello Franco. No âmbito da educação, o Estado convocou educadores para dar continuidade ao programa de reforma educacional, iniciado em 1929. Em 1932, estaria consolidado o Movimento da Escola Nova.

No campo da museologia, o esforço de promover ações integradoras pode ser melhor percebido na proposição tanto temática quanto cronológica, da criação de museus federais. Criou-se durante o período do Estado Novo, em diversos estados e em tão curto período, quatro museus históricos federais: o Museu da Inconfidência, em Ouro Preto (MG, 1938); o Museu Imperial, em Petrópolis (RJ, 1939); o Museu das Missões, em Santo Ângelo (RS, 1940); e o Museu do Ouro, em Sabará (MG, 1945). A compreensão do processo de formação, sob o incentivo do Estado, desses acervos, visando a entendê-los em seu conjunto, é um tema interessante, que mereceria ser aprofundado. Tal estudo não poderia deixar de ater-se à análise das razões que priorizaram ações da preservação, à época, de determinado conjunto de objetos históricos; e verificar a condição atual desses acervos e de seus critérios expositivos ${ }^{42}$.

No conjunto de museus federais, pode-se percorrer os períodos Bandeirista (no Museu das Missões), Colonial (no do Ouro), Imperial (no da Monarquia) e Republicano (no da Inconfidência). Essa rede nacional de museus (se assim podemos denominá-la) - temática, multirregional, de caráter integrador e evolutivo dos acontecimentos ligados à história, criada sob o prisma de formação do Estado Nacional - parece ter sido referência importante para a definição do modelo delineado por Stein na implantação da rede dos MHP no âmbito estadual.

Por uma museologia paulista

Como apontado anteriormente, no Arquivo VSC (Dema-SEC), não foi encontrada nenhuma correspondência entre Stein e outros diretores de museus da cidade de São Paulo. Não há sequer menção de esforços de colaboração entre - Museu Paulista e os MHP, tanto na orientação de cursos de museologia que pudessem habilitar profissionais para suprir as necessidades organizacionais dos museus em formação, quanto sobre a formação do acervo propriamente dito desses museus.

A falta de correspondência com outras instituições congêneres em São Paulo e no Brasil demonstra o quanto era profundo o isolamento de Stein e, conseqüentemente, do Serviço de Museus Históricos e Pedagógicos, durante todo o período que compreendeu a publicação dos decretos e a instalação
41. O Museu das Missões, em São Miguel das Missões, RS, foi criado em 1937, projeto de Lúcio Costa e colaboração de Lucas Mayerhofer e Paulo Thedim Barreto. "O projeto do museu resultou do trabalho sistemático de pesquisa e levantamento das construções e objetos encontrados nas ruínas de Sete Povos das Missões, primeira atividade de Lúcio Costa no Serviço de Patrimônio Histórico e Artístico Nacional (Sphan). Cf. Guilherme Wisnik (2001, p. 60).

42. Em visita recente (2008) ao Museu da Inconfidência (Ouro Preto), foram verificadas mudanças nos conjuntos de objetos expostos, bem como nova orientação no projeto expositivo, nos textos, nas legendas e nas fichas de identificação. 
43. Ver Gustavo Dodt Barroso (1944). efetiva de 63 museus. De 1957 a 1970, o Serviço de Museus Históricos e Pedagógicos contou somente com o empenho de seu diretor e o auxílio de um técnico.

Como alternativa ao seu isolamento e prevendo a necessidade urgente de formar diretores e funcionários capazes de, num curto prazo, assumirem a empreitada de formação dos acervos dos museus recém-instalados, Stein organiza um rápido Curso de Museologia, ministrado por ele, nas diversas cidades-sede dos museus. Tal iniciativa contava ainda, com o apoio da Secretaria de Educação, que instituía ponto facultativo à data de realização do curso. Dessa maneira, Stein planejou a rápida formação de um contingente enorme de servidores-diretores. Em poucos meses, percorreu diversas cidades, em um tempo em que eram exíguos a condição de ensino e o estudo da museologia. Conforme seu intuito, realizou prodigiosamente, durante os anos de 1956 a 1964, diversos cursos, atingindo um elevado número de participantes nas várias cidades do interior do estado.

Na capital, além do Museu Paulista, eram poucos os locais onde poderiam ser encontradas referências sobre os diversos campos que compreendem o estudo e a prática da museologia. Então, quais seriam as fontes de referência adotadas na formação de equipes técnicas para servir aos MHP?

No Arquivo VSC (Dema-SEC), foram encontradas cartas de Stein sugerindo aos diretores dos museus, a leitura de Introdução à técnica de museu, de autoria de Gustavo Barroso (1946-1947). A influência que Barroso possa ter exercido em relação à atividade de Stein e à museologia em São Paulo merece ser aprofundada em estudos oportunos, porém, num primeiro momento, podemos destacar a semelhança existente entre o curso rápido de museus, ministrado por Stein e o curso Técnica de Museu, criado por Barroso43, em 1932, no Museu Histórico Nacional, no Rio de Janeiro.

O programa do curso de Barroso era organizado em três módulos. No 1o ano, Parte Geral (ou noções gerais que servissem a qualquer museu), estudavam-se a organização de museus (arrumação, classificação, catalogação) e a restauração de objetos e monumentos. No $2^{\circ}$ ano, Parte Básica, forneciam-se noções técnicas para ingresso na parte especializada do estudo. Eram transmitidas noções de Cronologia, Epigrafia, Paleografia, Diplomática, Bibliografia e Iconografia. No 3o ano, Parte Especializada, propunha a aplicação da teoria à prática. Nesta etapa, era estudada a classificação pormenorizada dos objetos de museus de caráter histórico, como documentos, relíquias, heráldica, bandeiras, condecorações, armaria, arte naval, viaturas, arquitetura, mobiliário, indumentária, cerâmica, cristais, ourivesaria, prataria e bronzes, instrumentos de suplício e mecanismos.

Já o curso de Stein era destinado a ministrar noções básicas de organização de museus e, ao mesmo tempo, demonstrar a imensa utilidade que tais instituições podiam significar para o desempenho do trabalho educativo das escolas. O programa era composto de quatro aulas, proferidas em dois dias consecutivos. No primeiro, eram realizadas duas aulas: História dos Museus, e 
Técnica dos Museus. No segundo, Numismática Brasileira, e História do Brasil, interpretada em função da história do município.

A ordem e o tema das três primeiras aulas seguem o programa proposto por Barroso, principalmente quanto à definição do roteiro de aulas, partindo de assuntos mais genéricos para chegar aos mais específicos. Um dos assuntos que Stein costumava abordar em seus cursos era a Numismática. Não foram encontradas razões que pudessem justificar a predileção pela Numismática, a não ser um fato curioso. Stein tinha como costume, em todas as inaugurações de museus, doar cédulas antigas. Costumava realizar a primeira doação para o museu e, com isso, cumpria sua parte no compromisso cívico da empreitada ${ }^{44}$. Tal gesto servia como exemplo motivador para que a comunidade local se envolvesse diretamente na doação de peças e participasse da formação dos acervos dos "seus museus" (Figura 12).

No curso proposto por Stein, porém, o que se destaca como particularidade é o tema da quarta e última aula: História do Brasil, interpretada em função da história do município. Para proferir essa aula, Stein, sempre que

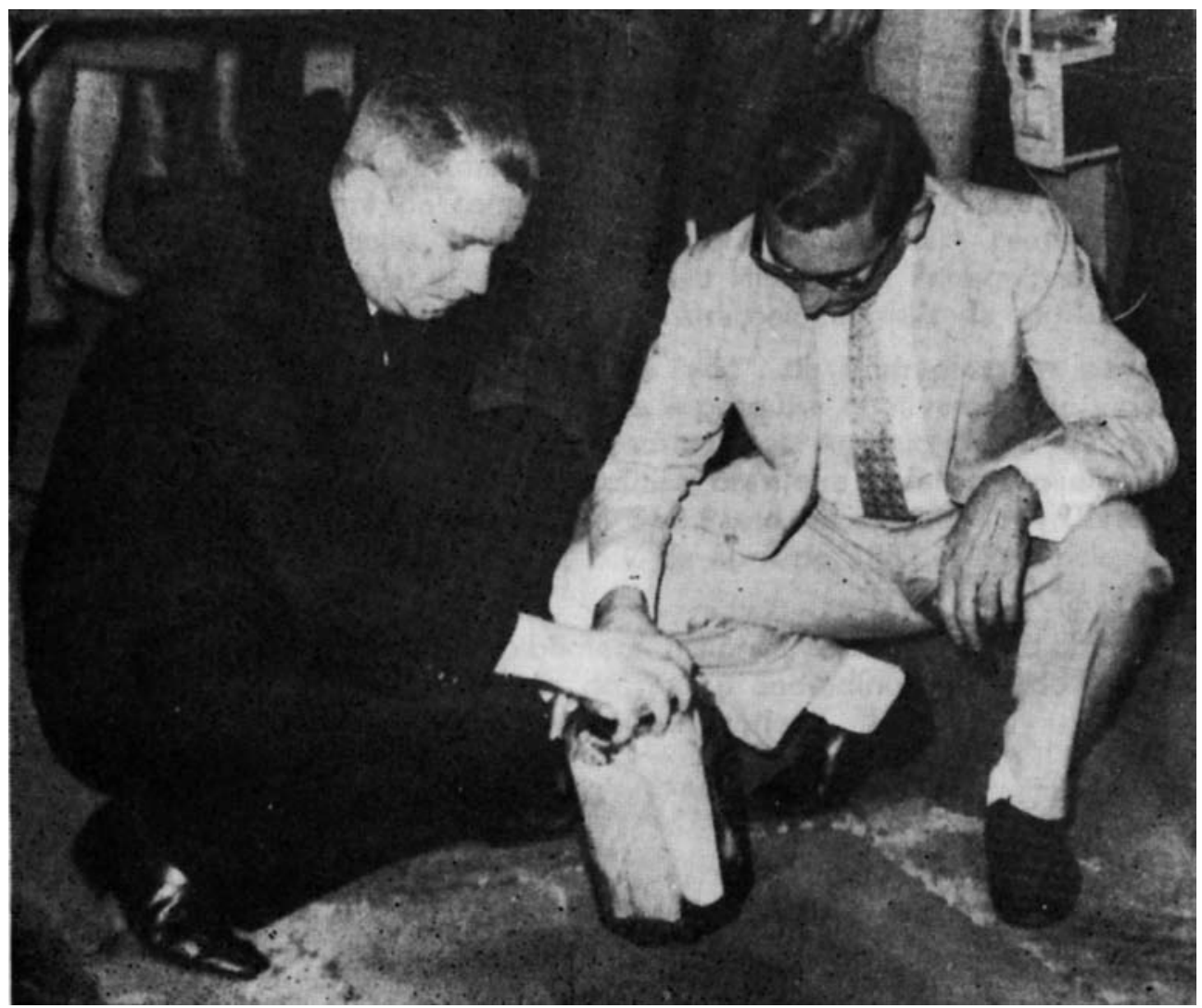

Figura 12 - O Prefeito Silvio Venturolli e o Diretor do Serviço de Museus Históricos colocam jornais, a Ata e moedas correntes na pedra fundamental do Museu Marechal Rondon, 23 de agosto de 1965. In: CAMPOS, Vinício Stein. Elementos de Museologia. V. 3. São Paulo: Secretaria de Cultura, Esportes e Turismo, ca. 1970. p. 136.
44 Segundo o artigo Cultura está apenas na lei, no Jornal de Ourinbos (19 set. 1972), Vinício Stein doou 70 moedas ao MHP Antônio Carlos de Abreu Sodré (Ourinhos). Cf. Arquivo VSC, V. Ourinhos, Dema-SEC. 

do Arquivo VSC, Dema-SEC. possível, convidava sócios correspondentes do IHGSP ou do Instituto Histórico da cidade onde o curso estava sendo realizado. $\bigcirc$ estudo do tema pode ter-se apoiado na expressiva produção historiográfica do IHGSP, pois uma pesquisa na Revista do IHGSP (1 894-1964) revelou a publicação de cerca de 350 artigos sobre o histórico de origem de diversas cidades-sede dos MHP. Nos 27 volumes que compõem o Arquivo VSC (Dema-SEC) também estão reunidos textos sobre o histórico de origem das cidades. Muito provavelmente esse material também serviu às suas conferências realizadas nas datas inaugurais dos museus. A exposição sobre o tema das cidades, da última aula, tinha um claro objetivo: terminava por justificar a todos os presentes a escolha do patrono e de sua relação com a cidade. Também era momento oportuno para Stein contribuir para a propagação de uma visão integrada da história, em que a história do município estaria muito mais atrelada à perspectiva estadual do que aos acontecimentos locais e regionais.

A eficácia na disseminação do curso rápido de Stein pelas diversas cidades do interior foi possível, em grande parte, devido à sua estreita relação com o secretário de Educação do estado e com os prefeitos das cidades. Tais órgãos deram intenso apoio à arregimentação dos professores nas diversas cidades-sede. A divulgação dos cursos era realizada tanto pela prefeitura e pelos jornais, como pela escola pública local, garantindo quase sempre a presença de um grande número de participantes. Após o término do curso, o Serviço de Museus Históricos expedia aos participantes um certificado, considerado título para todos os concursos do magistério público ${ }^{45}$. $O$ curso destinava-se principalmente a professores (primários e secundários), mas deles também participavam alunos das escolas normais. Em acordo com as escolas públicas locais, a Secretaria de Educação garantia ponto facultativo a todos os participantes das aulas, durante os quatro dias em que o curso era proferido. Uma vez concluído o curso e com a expedição dos certificados, era mais fácil para Stein solicitar à Secretaria de Educação a transferência de professores, quase sempre indicados por ele próprio ou por prefeitos das cidades, para assumirem o cargo da direção do museu. A intensa participação de professores nos cursos de museologia pôde garantir, em certa medida, a sustentação de outra função (além da "histórica") designada aos MHP: a função "educadora" dos museus.

Dados expressos em correspondências existentes no Arquivo VSC (Dema-SEC) atestam que, de 1956 a 1964, foram realizados cursos em diversas cidades paulistas. O número de participantes surpreende: Campinas (1956), 89 participantes; Piracicaba (1956), 130; Capivari (1957), 300; Pindamonhangaba (1957), 300; São Carlos (1958), 250; Botucatu (1963), 400; Araçatuba (1964), 976 participantes ${ }^{46}$. Além dos cursos de museologia, o / Seminário dos Museus Históricos e Pedagógicos, evento realizado nos dias 13 e 14 de junho de 1972, na sede do IHGSP, também obteve destacada participação de diretores e professores, pois reuniu representantes de quarenta museus do interior paulista $^{47}$. 
Na década de 1960, o assunto da expansão dos MHP foi evoluindo de tal maneira, que o governo paulista pretendeu criar a primeira Faculdade de Museologia do Estado de São Paulo48, em 1968. Na época, tal iniciativa não foi levada a cabo, mas em 1977, é criado o Instituto de Museologia de São Paulo (IMSP), na Fundação Escola de Sociologia e Política do Estado de São Paulo, sob iniciativa de Waldisa Russio ${ }^{49}$. Nesse período, Russio também integrou a equipe do Grupo Técnico do Dema-SEC, onde pôde acompanhar Stein em algumas das visitas técnicas aos MHP. Embora não tenha sido possível a criação da Faculdade de Museologia almejada por Stein, não devemos deixar de considerar a repercussão que o volume de cursos proferidos nas inúmeras cidades do interior paulista representou para o delineamento do que tenha sido a prática da museologia no âmbito público, principalmente nas décadas de 1960 e de 1970, por todo o estado de São Paulo. Mais ainda, tal prática pode ter incorrido na caracterização de um certo modo de concepção de museu histórico, uma vez que os professores-diretores foram os próprios agentes, no processo de formação dos acervos, de organização expositiva e de desempenho das atividades cotidianas dos MHP, sempre sob a supervisão de Stein. Foi esse o gerenciamento que acabou vigorando por longos anos, e que também propiciou para alguns diretores, a permanência na direção dos museus, por cerca de vinte anos.

A estratégia adotada por Stein para suprir as diversas dificuldades provenientes de carência de equipe técnica, de exíguo orçamento, de instalações inadequadas e de longas distâncias da capital - garantiu, em certa medida, a perpetuação e a cristalização de um determinado sistema administrativo, organizacional e de formação de acervos, em vigor por cerca de cinqüenta anos.

Entretanto, nas últimas duas décadas, alguns dos museus como o MHP Bernardino de Campos (Amparo), passaram por reformas e puderam reorganizar a exposição de seus acervos por meio de critérios mais atualizados, sob orientação técnica do DEMA-SEC (Figuras 13 a 15).

A realização de estudos que enfoquem a atual dinâmica particular desses museus, bem como verifiquem em que medida, ao longo dos últimos anos, seus diretores contestaram ou não tal sistema, será de extrema importância para avaliar a prosperidade do modelo estabelecido por Stein.

Por uma função educadora

A inclinação de Stein à ideologia que configurou as ações empreendidas na educação e na cultura nos anos 1930, permitiu que, por meio da tipologia de seu acervo, de suas atividades e do engajamento com a comunidade local, os MHP perpetuassem a vocação de, prioritariamente, moldar uma nação por meio da valorização de seus heróis e de importantes acontecimentos históricos.
47. Ofício expedido por Vinício Stein ao prefeito da Cidade de São Paulo, em 19 jun. 1972. Arquivo VSC, Dema-SEC.

48. Cf. o artigo Santos contará com Faculdade de Museologia, na $A$ Tribuna de Santos (16 maio 1967). Arquivo VSC, v. Santos, DemaSEC

49. O curso de Museologia, do Instituto de Museologia de São Paulo da FESP-SP, perdurou até 1990 , data do falecimento de Waldisa Russio. 


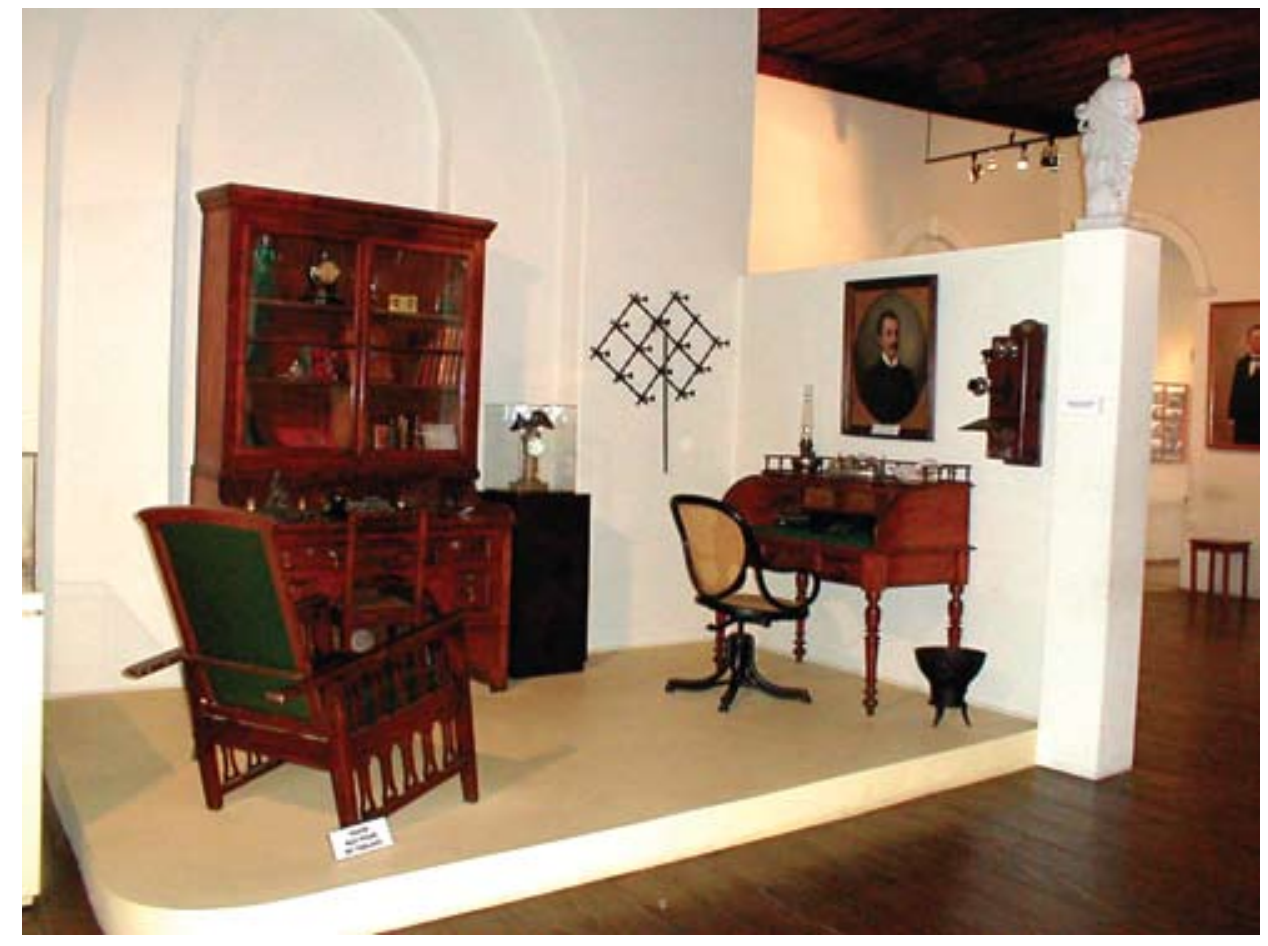

Figura 13 - Aspecto, pós-reformulação, da exposição no MHP Bernardino de Campos (Amparo, São Paulo). Simulação de Gabinete de trabalho de Bernardino de Campos. Fotografia de Simona Misan, 2005.
Figura 14 - Aspecto, pós-reformulação, da exposição no MHP Bernardino de Campos (Amparo, São Paulo).Simulação de interiores de residências do início do séc. XX na cidade de Amparo. Fotografia de Simona Misan, 2005.

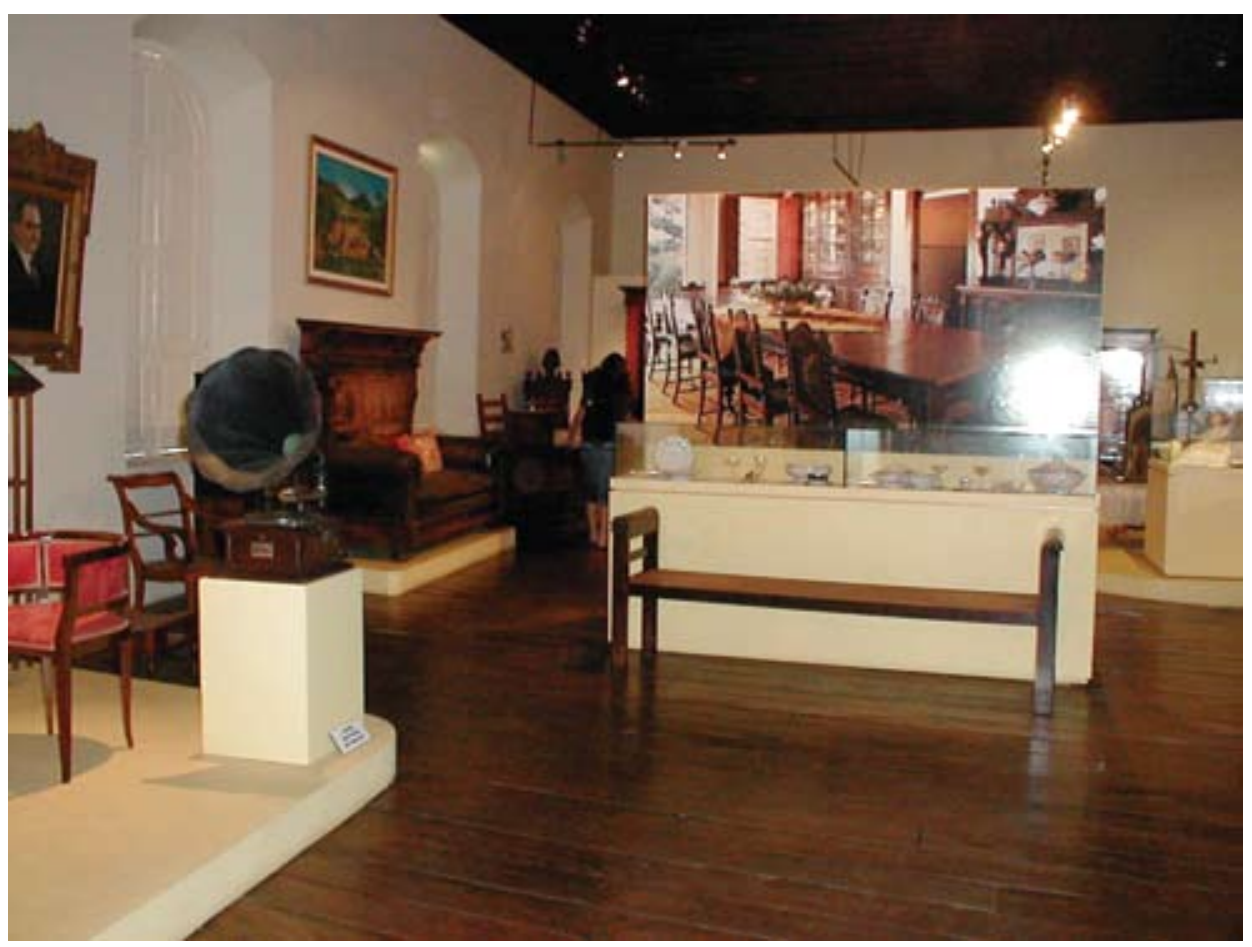

Anais do Museu Paulista.v. 16. n.2. jul.-dez. 2008. 


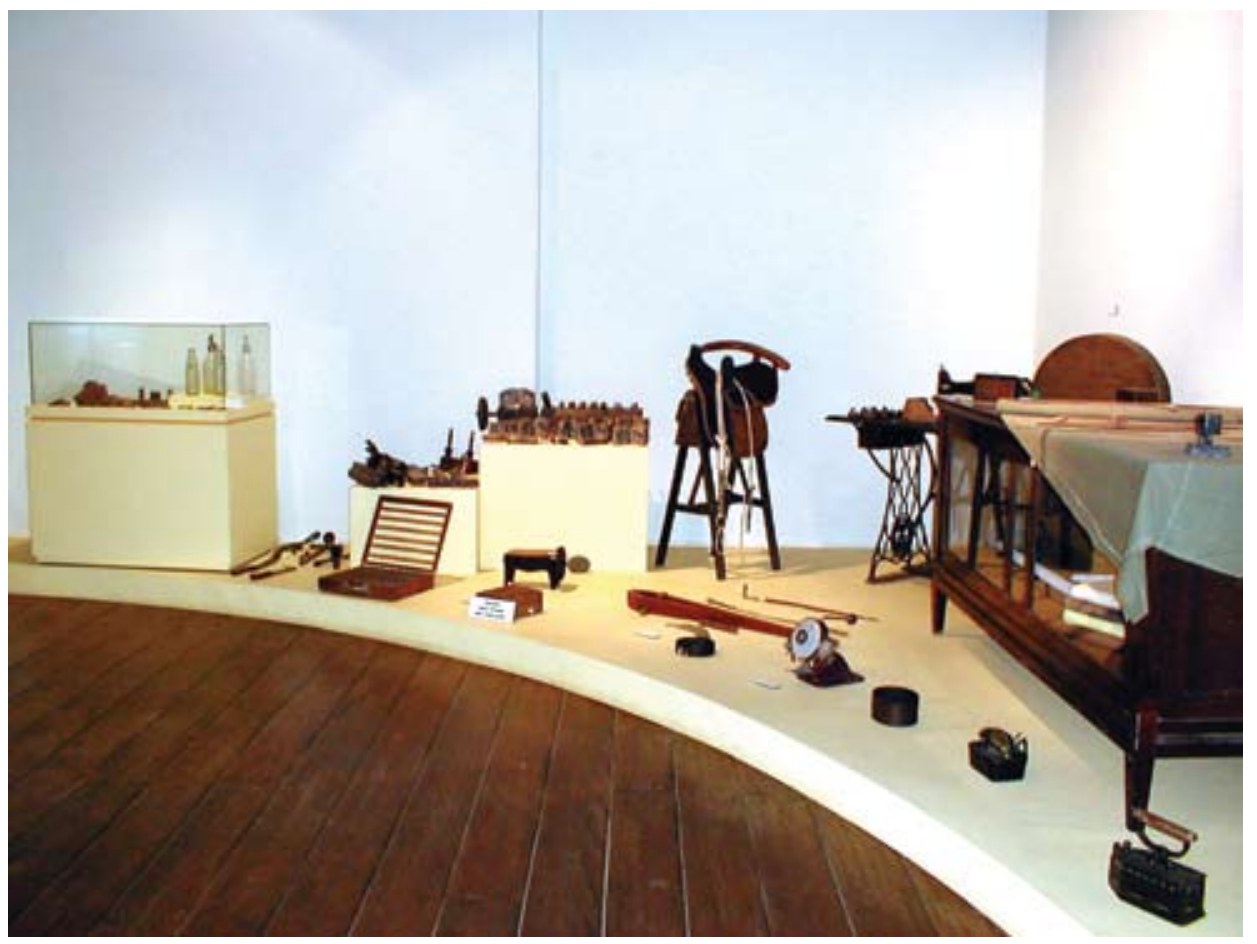

Figura 15 - Aspecto, pós-reformulação, da exposição no MHP Bernardino de Campos (Amparo, São Paulo).Vista da sala onde estão expostos alguns dos instrumentos de trabalho utilizados por trabalhadores e operários da cidade de Amparo.Fotografia de Simona Misan, 2005.

A aliança do poder público - representado pela Secretaria de Educação e, posteriormente, pela Secretaria de Estado da Cultura de São Paulo - com educadores e servidores (em especial os filiados ao IHGSP) colaborou para que tal prática preservasse e perpetuasse, até os dias atuais, ideais antigos, alheios às mudanças históricas. A reflexão sobre tais fatores pôde contribuir para um entendimento do que possa ter conceituado, quanto a seu caráter pedagógico, a criação dos MHP. Em grande parte, a longa permanência do projeto históricoeducativo, como fora originalmente concebido no ano de 1956 no quadro administrativo do Estado, credencia à rede certa adequação aos ideais políticoculturais oficiais em voga prioritariamente nas décadas de 1950 e 1960. Deve ainda ser lembrado que, durante esse período e, principalmente, nos anos que sucederam o golpe de 1964 até a reabertura política na década de 1980, os MHP tiveram seus anos mais prósperos. Em grande parte, os museus constituíram seus acervos em meados da década de 1970, notadamente por meio de doações particulares, e desempenharam intensa atividade junto ao meio escolar, na realização de concursos, na elaboração de trabalhos (biografias sobre os patronos e histórico da cidade) e visitas de grupos escolares. Dessa maneira, entendemos que as atribuições dos MHP e sua manutenção no quadro oficial da Secretaria da Educação (e depois na de Cultura) corresponderam ao que se 
50. Não foi identificada, na pesquisa empreendida sobre os MHP na totalidade das bibliotecas e dos arquivos consultados (IHGSP; Arquivo VSC e Arquivo MHP, Dema-SEC; Arquivo Museu Imperial; Arquivo Waldisa Russio; IMS-FESP e IEB-USP Cedoc-FGV; e bibliotecas. Ver Simona Misan

51. Ver Simona Misan (2005, p. 94-120) pretendeu dos museus históricos do Governo do Estado de São Paulo, e de sua relação com a comunidade e a educação, na década de 1970 e meados da de 1980, período em que vigorou a ditadura militar.

Muito preocupados em atender às necessidades pedagógicas requeridas em seu tempo, bem como em reunir material histórico representativo e enfrentar a inexistência de orçamento e local físico adequado, esses museus afirmaram, e continuam a afirmar, sua vocação, tal qual concebida em 1956, quando estavam plenamente consoantes com as propostas pedagógicas de cunho cívico propagadas pelos escolanovistas. É a primeira rede de museus de tal natureza em São Paulo e no Brasil. É, também, o primeiro projeto de criação de uma rede de museus históricos e pedagógicos da Secretaria de Educação, em 1956, e da Secretaria de Cultura do Governo do Estado, criada em 1968, data em que esta Secretaria passa a exercer sua administraçãa ${ }^{50}$. Na pesquisa empreendida, não foram identificadas iniciativas similares à de Vinício Stein, tampouco a existência de outros museus que tivessem a denominação de "Histórico e Pedagógico". Contudo, não deixamos de analisar o histórico de criação e o ideário de museus que, de alguma maneira, pudessem aproximar-se (ou mesmo influenciá-lo) do plano de implantação de museus empreendido por Stein, entre eles, o Museu Escolar Nacional ou Museu Pedagógico Nacional (1883, RJ), o Museu Pedagógico do Pedagogium (1890, RJ), e o Museu Pedagógico Central (1929, RJ) $)^{51}$.

As razões de ter-se mantido como o único projeto histórico-educativo oficial do período - bem como, passados cerca de quase vinte anos após o término da ditadura, os MHP ainda se manterem em seu formato original - dizem respeito não somente às questões levantadas no estudo ora apresentado, mas também à trajetória do que foi tomado como encaminhamento de propostas pelos órgãos competentes de gestão pública da cultura no passado e do que vai ser considerado no presente.

A municipalização da rede de MHP, coordenada pelo Dema-SEC desde 1998, pode ser a primeira iniciativa no que diz respeito à avaliação do valor que esses museus representam, à importância da participação ou não do poder público em seu desempenho e, para finalizar, à atribuição que a cidade dá ałualmente ao "seu museu histórico".

\section{REFERÊNCIAS}

ABREU, Regina. Sangue, nobreza e política no templo dos imortais. Rio de Janeiro: Editora da UFRJ, 1991.

ABREU, Regina. A fabricação do imortal. Memória, bistória e estratégia de consagração no Brasil. Rio de Janeiro: Rocco, 1996.

ABUD, K. O sangue intimorato e as nobilíssimas tradições. A construção de um símbolo paulista: o bandeirante. 1986. Tese de Doutoramento - Departamento de História, da Faculdade de Filosofia, Letras e Ciências Humanas da Universidade de São Paulo, 1986. 
AZEVEDO, Fernando de. Novos caminhos e novos fins. A nova política de educação no Brasil. São Paulo: Nacional, 1931.

AZEVEDO, Fernando de. Reforma do ensino no Distrito Federal. São Paulo: Melhoramentos, 1927-30.

AZEVEDO, Fernando de. A cultura brasileira: introdução ao estudo da cultura no Brasil. Rio de Janeiro: IBGE, 1943.

BANCO SAFRA. Museu Imperial, Petrópolis. São Paulo: Banco Safra, 1992.

BARROSO, Gustavo D. O Curso de Museus e Regulamento do Curso de Museus. Anais do Museu Histórico Nacional, Rio de Janeiro: MHN, vol. 5, p. 191-204, 1944.

BARROSO, Gustavo D. Introdução à técnica de museus. Rio de Janeiro: Olímpica, 1946-1947.

BACKHEUSER, Everardo. A técnica da pedagogia moderna: teoria e prática da escola nova, Rio de Janeiro: Civilização Brasileira, 1934.

BOMENY, H. Os intelectuais da educação. Rio de Janeiro: Jorge Zahar, 2001.

CAMPOS, Vinício Stein. Museus e monumentos bistóricos de São Paulo. São Paulo: Secretaria de Estado dos Negócios da Educação, 1960.

CAMPOS, Vinício Stein. Elementos de Museologia. São Paulo: Secretaria de Cultura, Esportes e Turismo, [ca. 1970]. $11 \mathrm{v}$.

CARVALHO, J.M. de. A formação das almas. O imaginário da República no Brasil. São Paulo: Companhia das Letras, 1998.

CESAR, Waldo. Tenente Pacífico: um romance da Revolução de 32. Rio de Janeiro: Record, 2002.

FERREIRA, Antonio Celso. A epopéia bandeirante. Letrados, instituições, invenção histórica, 1870-1940. São Paulo: Editora Unesp, 2002.

GODOY, Solange de Sampaio (Ed.). O Museu Histórico Nacional. São Paulo: Banco Safra, 1989.

IHGSP. Revista do IHGSP, São Paulo, v. 60, n. 51, 1964.

LACOMBE, L. L.; COTRIM, A. Museu Imperial. Petrópolis: Colorama, 1987.

LIMA, Patricia Ferreira de Souza. Petrópolis: progresso e tradição nos trabalhos da memória. Dissertação (Mestrado em História Social da Cultura) - Faculdade de História, Pontifícia Universidade Católica do Rio de Janeiro, 2001.

LOVE, J. A locomotiva: São Paulo na federação brasileira, 1889-1937. Rio de Janeiro: Paz e Terra, 1982.

MENDONÇA, Edgar Sussekind de. A extensão cultural nos museus. Rio de Janeiro: Imprensa Nacional, 1946.

MENDONÇA, Edgar Sussekind de. Ensino e Cultura. Rio de Janeiro: 1940. 
MENESES, Ulpiano T. Bezerra de. O museu na cidade, a cidade no museu: para uma abordagem histórica dos museus de cidade. Revista Brasileira de História, São Paulo, v. 5, n. 8-9, p. 197205, set.- abr. 1984-1985.

MENESES, Ulpiano T.Bezerra de et al. Alfaias, apetrechos, trecos: os móveis. In: Como explorar um museu bistórico. São Paulo: MP-USP, 1992. p. 15-18.

MINISTÉRIO DA EDUCAÇÃO E SAÚDE. Museu Imperial de Petrópolis. Rio de Janeiro: Imprensa Nacional, 1947.

MISAN, Simona. A implantação dos museus históricos e pedagógicos do estado de São Paulo (1956-1973). 2005. Tese (Doutorado em História Social) - Departamento de História, da Faculdade de Filosofia, Letras e Ciências Humanas da Universidade de São Paulo, 2005.

NEME, Mario. Utilização cultural de material de museu. Anais do Museu Paulista, São Paulo, t. 18, p. 7-62, 1964 .

ROQUETTE-PINTO. A História Natural dos pequeninos. Rio de Janeiro: 1925.

ROQUETTE-PINTO. Seixos rolados: estudos brasileiros. Rio de Janeiro: Mendonça Machado, 1927.

RUSSIO, Waldisa. Algumas considerações sobre uma política cultural para o estado de São Paulo. In: Seminários Permanentes do Museu da Casa Brasileira. São Paulo: Museu da Casa Brasileira - SEC. Arquivo WR, Caixa 41, IEB-USP.

SERRANO, Jonathas A. da S. Como se ensina bistória. São Paulo: Melhoramentos, 1935.

SOUZA, R. F. de. Templos de civilização: a implantação da escola primária graduada no estado de São Paulo, 1899-1910. São Paulo: Editora Unesp, 1998.

SCHWARCZ, Lilia K. Moritz. Os guardiões da nossa bistória oficial: os institutos históricos e geográficos brasileiros. São Paulo: Idesp, 1989.

WISNIK, Guilherme. Lúcio Costa. São Paulo: Cosac \& Naify, 2001. (Espaços da Arte Brasileira ).

VENÂNCIO FILHO, Francisco. A educação e seu aparelhamento moderno. 1941.

VENÂNCIO FILHO, Francisco. Função Educadora dos Museus. 1939.

VENÂNCIO FILHO, Francisco; SERRRANO, Jonathas. Cinema e Educação. 1930.

Artigo apresentado em 2/2008. Aprovado em 8/2008. 